Article

\title{
Fertigation of Ajwain (Trachyspermum ammi L.) with Fe-Glutamate Confers Better Plant Performance and Drought Tolerance in Comparison with $\mathrm{FeSO}_{4}$
}

\author{
Qasim Ali ${ }^{1, *}$, Sumreena Shahid ${ }^{1}$, Shafaqat Ali ${ }^{2,3, *}{ }^{\circ}$, Mohamed A. El-Esawi ${ }^{4}(\mathbb{D}$, \\ Abdullah I. Hussain ${ }^{5}{ }^{(1)}$, Rashida Perveen ${ }^{6}$, Naeem Iqbal ${ }^{1}$, Muhammad Rizwan ${ }^{2}{ }^{(D)}$, \\ Mohammed Nasser Alyemeni ${ }^{7}$, Hamed A. El-Serehy ${ }^{8}$ (D) and Fahad A. Al-Misned ${ }^{8}$ \\ 1 Department of Botany, Government College University, Faisalabad 38000, Pakistan; \\ sumreenashahid1992@gmail.com (S.S.); drnaeem@gcuf.edu.pk (N.I.) \\ 2 Department of Environmental Sciences and Engineering, Government College University, \\ Faisalabad 38000, Pakistan; mrazi1532@yahoo.com \\ 3 Department of Biological Sciences and Technology, China Medical University, Taichung 40402, Taiwan \\ 4 Botany Department, Faculty of Science, Tanta University, Tanta 31527, Egypt; \\ mohamed.elesawi@science.tanta.edu.eg \\ 5 Department of Applied Chemistry \& Biochemistry, Government College University, \\ Faisalabad 38000, Pakistan; abdullahijaz@gcuf.edu.pk \\ 6 Department of Physics, University of Agriculture, Faisalabad 38000, Pakistan; 2007ag942@uaf.edu.pk \\ 7 Botany and Microbiology Department, College of Science, King Saud University, \\ Riyadh 11451, Saudi Arabia; mnyemeni@ksu.edu.sa \\ 8 Department of Zoology, College of Science, King Saud University, Riyadh 11451, Saudi Arabia; \\ helserehy@ksu.edu.sa (H.A.E.-S.); almisned@ksu.edu.sa (F.A.A.-M.) \\ * Correspondence: drqasimali@gcuf.edu.pk (Q.A.); shafaqataligill@yahoo.com (S.A.)
}

Received: 21 June 2020; Accepted: 25 August 2020; Published: 31 August 2020

\begin{abstract}
Shortage of fresh water limits crop yield. Different ways including the use of chemicals are being employed for the improvement in yield through induction of plant performance. In the present study, ajwain plants grown under water stress and normal irrigation conditions were fertigated with Fe-chelated glutamate (Fe-Glu), as a foliar spray for the induction of plant performance in comparison with $\mathrm{FeSO}_{4}$. Water shortage adversely affected the plant growth and seed yield, associated with decreased uptake of water and nutrients, along with perturbations in different physio-biochemical attributes. On the other hand, Fe-Glu and $\mathrm{FeSO}_{4}$ fertigation improved plant performance under water stress and normal irrigation conditions. Fe-Glu and $\mathrm{FeSO}_{4}$ fertigation ameliorated the adverse effects of water stress on biomass and seed production, improved water and nutrients uptake, increased the accumulation of essential amino acids, leaf chlorophyll and carotenoids, and reduced the lipid peroxidation due to the induction of antioxidative mechanisms. Fertigation of Fe-Glu and $\mathrm{FeSO}_{4}$ also improved Fe uptake and conferred better mobility and availability of Fe for plants when applied in chelated form. Overall, a significant improvement in ajwain performance under water stress and normal irrigation conditions was recorded due to the fertigation of Fe-Glu as compared with $\mathrm{FeSO}_{4}$.
\end{abstract}

Keywords: water stress; water relations; antioxidative mechanism; amino acids; seed yield; lipid peroxidation; nutrient uptake

\section{Introduction}

Shortage of fresh water along with the changes in global environmental conditions have created a problem for the agricultural researchers to fulfill the food demand for the increasing world population 
with a target to fulfill this demand till 2050 [1,2]. Global environmental changes have altered the ongoing rainfall patterns all over the world, resulting in drought stress in some areas and flooding in others [3]. Under such conditions, the demand for food is increasing due to the deleterious effects of drought on crop production [4,5]. Different ways or techniques are being employed to handle this problem and improve and conserve plants. These include improved agronomic practices with water conservation, genetic characterization, developing and selection of drought tolerant genotypes with better production as well as the exogenous use of organic and inorganic chemicals through different modes [6-10]. Under soil water deficit conditions, the perturbations in plant water relations is the foremost effect along with reduced uptake of nutrients and disturbed cellular ion homeostasis, and this situation becomes more severe when the soil is already deficit to specific micro or macro nutrients [11]. Among different essential micro-nutrients, iron (Fe) is an important one due to its multiple roles in plant cellular metabolic activities linked to enhanced plant growth, metabolism, and morphology [12]. It is important for maintaining the function and structure of chloroplast involved in chlorophyll biosynthesis [13]. It also plays a crucial role as a prosthetic group of many enzymes, including peroxidases, cytochromes and catalases. Young and Ajami [14] reported its active role in synthesis of cellular protein. As an important component of enzymes and protein, it also plays an active role in many biological processes, including photosynthesis and nitrogen fixation, as well as synthesis of metallo-protein that need Fe to perform their proper functioning [15]. As a part of Fe-S centers, it also plays an important role in the electron transport chain [16].

The presence of inadequate concentration of Fe in plants results in reduced growth and yellowing of leaves [13]. Studies reveal that Fe deficiency in rooting medium results in reduced nutritional quality and seed yield [17]. Iron is required in an optimal concentration in plants for better growth because it helps plants in performing their biochemical and physiological functions in a proper way. The excessive concentration of Fe plants in ionic form is potentially toxic and results in excessive formation of reactive oxygen species, resulting in lipid peroxidation by damaging the cellular membranes $[13,18]$. Iron also has a very low solubility and bioavailability under low soil osmotic potential [19,20], resulting in restricted plant productivity and low quality. To fulfill the Fe deficiency, different inorganic fertilizers are being used in soil or foliar spray. These include mainly the use of $\mathrm{FeSO}_{4}, \mathrm{FeCl}$ as foliar spray or soil application, and the use of $\mathrm{FeSO}_{4}$ is most common, but $\mathrm{FeSO}_{4}$ use has some drawbacks in crop plants [21]. As a chemical in nature, its use is not eco-friendly [22]. It is well reported that chemical fertilizers such as $\mathrm{FeSO}_{4}$ have raised issues including the significant risks that may happen for animal, humans and plants, as well as for the ecosystem's health [23,24]. Generally, used fertilizers are simple chemicals and readily available in ionic form that undergo various harmful reactions in soil solution as well as in cells after absorbing, resulting in low uptake and disturbed metabolism [24-26]. These include the complex formation, volatilization, precipitation, fixation and leaching that reduce the efficiency of chemical fertilizers [24,27]. It has been found that Fe availability in plants is also reduced due to the different cellular oxidation reactions [21].

To minimize the adversities of such effects, the interest in the use of eco-friendly biofertilizers is increasing, including the micro-nutrient chelated amino acids [21]. In chelation, the uptake and availability of the micro-nutrients increase with no or less chances of oxidation of the nutrients [24]. The key feature that makes the use of aminochelate fertilizers as eco-friendly ones with higher efficiency is the stability of the chelated bond between micronutrient cations and amino acids in nutrient solution as compared with its use as a chemical fertilizer [21,24,28].

Additionally, in the case of chelation with an organic molecule, both parts of the chelation play a significant role in different cellular metabolic activities [29]. For example, along with the beneficial effects of micro-nutrients, the chelated amino acid metabolism also plays a key role in improving stress tolerance of plants [7,29]. Among different amino acids, glutamate plays multiple roles in growth improvement and other metabolic activities both under normal and stressful conditions. Studies revealed its role in the synthesis of lysine, arginine and orthenine as a precursor as well as its indirect role in various other metabolic activities [30,31]. Dinu et al. [32] reported that glutamate 
has an important role in osmotic adjustment of the stomatal guard cells as it controls the opening and closing of the stomata. The endogenous excessive accumulation of the glutamate under normal or stressed conditions or through its exogenous application, confirms its role as a signaling molecule in ameliorating the deleterious effects of multiple abiotic stresses [31]. For example, the exogenous application of glutamate on Brassica compestris reduced the negative impacts of salt and osmotic stress [33]. Ramos et al. [34] reported an endogenous increase in glutamate of Glycine max L. grown under water deficiency, resulting in the increased accumulation of many other amino acids along with its own accumulation. In another study conducted by Sadak et al. [35], it was found that exogenous application of glutamate as a foliar spray on faba bean reduced the deleterious impacts of salinity.

Ajwain is an aromatic herb belonging to the family umbelliferae (apiaceae). Its seed has a high amount of essential minerals, flavone $(7.1 \%)$, protein $(15.4 \%)$, carbohydrates $(38.9 \%)$, moisture $(8.9 \%)$ and fiber (11.9\%) [36]. The essential oil extracted from seeds of ajwain is being used in minor quantities in perfumery, food flavoring as preservatives and, most extensively, in folk medicines [36], especially for remedies of stomach disorders. Dry and hot fruit fomentation is externally applied on the chest for curing asthma, and a crushed fruit paste is applied for colic pains [37]. In many developing countries, this crop is ignored and mainly grown in dry and rainfed areas with no availability of water for irrigation, where it is facing the problem of yield losses. Moreover, in Pakistan, the ajwain crop faces the problem of a hot and dry environment during the onset of reproduction and harvesting growth stages.

Till now, no reports are available about the use of Fe-Glu for improving the plant performance and plant sensitivity to limited water supply as well as to overcome the plant Fe deficiency under water stressed conditions. So, in view of the information available, it was hypothesized that Fe-chelated glutamate might improve the plant performance and water stress tolerance, and will be helpful to overcome the plant Fe deficiency in ajwain plants grown under water stress and non-stressed conditions in comparison with $\mathrm{FeSO}_{4}$ due to its foliar application at vegetative stage. The aim of the study was to explore the comparative roles of different levels of Fe-Glu and $\mathrm{FeSO}_{4}$ to overcome the plant iron deficiency along with the induction of plant performance in view of different morphological attributes, biomass production, physio-biochemical parameters, oxidative defense mechanism, nutrient acquisition and seed yield. Furthermore, the present study aimed to find out the most effective level of Fe required for better seed yield.

\section{Materials and Methods}

Experimental site was a research area located in the Botanical Garden at Government College University Faisalabad (latitude $30^{\circ} 30^{\prime} \mathrm{N}$, longitude $73^{\circ} 10^{\prime} \mathrm{E}$ and altitude $213 \mathrm{~m}$ ). Water stress was maintained as the number of irrigations. Experiment was conducted in a factorial arrangement. Experimental area was divided into two main plots; each is specific to water stress level (normal irrigation and water stress with irrigation numbers). Each main plot was then divided into eight subplots corresponding to specific treatments. The different treatments used were No Spray (NS), Water Spray (WS), $\mathrm{FeSO}_{4}(0.25 \%), \mathrm{FeSO}_{4}(0.5 \%)$, Fe-Glu (0.25\%), and Fe-Glu (0.5\%). There were four rows of equal size in each subplot corresponding to the specific treatment. In each plot, one row was specified for NS, and the other one for WS, while the remaining two lines were specified to $0.25 \%$ level of $\mathrm{FeSO}_{4}$ or Fe-Glu. The same arrangement was followed for $0.5 \%$ level of $\mathrm{FeSO}_{4}$ or Fe-Glu. In each main plot out of eight subplots, four were allocated to $0.25 \%$ level and the other four for $0.5 \%$ level. The subplots in each main plot were distributed randomly to minimize the error due to edaphic factors. The same arrangement was followed for the other main plot. The complete layout plan of the experiment is given in Table S1 as a Supplementary Material.

\subsection{Soil Analysis}

The soil of the experimental site was sandy loam having organic matter $(1.15 \%)$ and available total $\mathrm{N}(0.73 \%)$ and $\mathrm{P}(8.6 \mathrm{ppm})$, with a saturation percentage of $34 \%$. The average $\mathrm{pH}$ and $\mathrm{EC}$ of the soil was 7.8 and $2.53 \mathrm{ds} . \mathrm{m}^{-1}$, respectively. The soil solution has the $\mathrm{HCO}_{3}{ }^{-}\left(4.93 \mathrm{meqL} \mathrm{L}^{-1}\right)$, soluble 
$\mathrm{CO}_{3}{ }^{2-}$ (traces), $\mathrm{SO}_{4}{ }^{-2}\left(1.98\right.$ meq L $\left.{ }^{-1}\right), \mathrm{Cl}^{-}\left(8.52\right.$ meq L $\left.{ }^{-1}\right), \mathrm{Ca}^{2+}+\mathrm{Mg}^{2+}\left(14.3 \mathrm{meq} \mathrm{L}{ }^{-1}\right), \mathrm{Fe}(0.041$ meq $\left.\mathrm{L}^{-1}\right), \mathrm{Na}\left(2.98 \mathrm{meq} \mathrm{L}^{-1}\right)$ and SAR $\left(0.086 \mathrm{meq} \mathrm{L}^{-1}\right)$. The soil's physical and chemical properties were assayed following Davis and Freitas [38].

\subsection{Application of Water Stress and Foliar Spray of Different Treatments}

During growing season (October/November 2018), the soil was irrigated well with canal water before seed sowing for field preparation. Healthy seeds of the ajwain (Trachyspermum ammi L.) locally known as Desi Ajwain were collected from the market and checked for germination before sowing. Then, the soil was ploughed well for seed sowing after 15 days of irrigation. Sowing of seeds was done at $\frac{1}{2}$ inch depth on 1st November 2018. The first irrigation was applied after 10 days of sowing. This irrigation was not included in water stress schedule. Second irrigation was applied after 15 days of first irrigation, to all the plots including the selected ones for water stress treatment. Later, the non-stressed plots were irrigated as per water requirement till maturity, but the plants selected for water stress treatment were watered twice, i.e., at fully vegetative and flowering stages only. The irrigated water was tested in terms of quality, having BOD $\left(1.50 \mathrm{~L}^{-1}\right), \mathrm{SAR}(0.85), \mathrm{pH}(7.6), \mathrm{EC}$ $\left(0.37 \mathrm{dS} \mathrm{m}^{-1}\right)$, acidity $\left(86 \mathrm{mg} \mathrm{L}^{-1}\right)$, alkalinity $\left(18 \mathrm{mg} \mathrm{L}^{-1}\right), \mathrm{HCO}_{3}+\mathrm{CO}_{3}\left(1.7 \mathrm{mg} \mathrm{L}^{-1}\right), \mathrm{SO}_{4}\left(0.9 \mathrm{meq} \mathrm{L}^{-1}\right)$, $\mathrm{PO}_{4}\left(0.114 \mathrm{mg} \mathrm{L}^{-1}\right)$, and $\mathrm{NO}_{3}\left(0.95 \mathrm{mg} \mathrm{L}^{-1}\right)$. Different minerals in irrigation water were $\mathrm{K}\left(4.29 \mathrm{mg} \mathrm{L}^{-1}\right)$, $\mathrm{P}\left(3.11 \mathrm{mg} \mathrm{L}^{-1}\right), \mathrm{N}\left(12 \mathrm{mg} \mathrm{L}^{-1}\right)$, As (1 ppb), Zn $\left(0.04 \mathrm{mg} \mathrm{L}^{-1}\right), \mathrm{Cu}\left(0.15 \mathrm{mg} \mathrm{L}^{-1}\right), \mathrm{Na}\left(0.34 \mathrm{mg} \mathrm{L}^{-1}\right)$, $\mathrm{Ca}\left(1.62 \mathrm{meq} \mathrm{L}^{-1}\right), \mathrm{Mg}\left(1.18 \mathrm{meq} \mathrm{L}^{-1}\right), \mathrm{Cl}\left(53.9 \mathrm{meq} \mathrm{L}^{-1}\right)$ and $\mathrm{Fe}\left(0.11 \mathrm{mg} \mathrm{L}^{-1}\right)$. The plants were thinned in a row to maintain the distance of 9 inches among plants, after 10 days of 1 st irrigation. However, row to row distance was kept 18 inches at the time of seed sowing. After three weeks of 2nd irrigation, different treatments were applied as foliar spray. Different concentrations of Fe-Glu and $\mathrm{FeSO}_{4}$ were prepared in water and before foliar spray, $0.1 \%$ twin- 20 was mixed in solution as surfactant. The $\mathrm{FeSO}_{4}$ and glutamate were of analytical grade purchased from Merck, Germany. The plants were sprayed with $\mathrm{Fe}-\mathrm{Glu}$ and $\mathrm{FeSO}_{4}$ by using the concentrations of $0.25 \%$ and $0.5 \%$ of each. The method given by Leu [39] was followed for preparation of Fe-Glu. Briefly, $260 \mathrm{~g}$ of $\mathrm{FeSO}_{4} \cdot 7 \mathrm{H}_{2} \mathrm{O}$ were dissolved in water $(150 \mathrm{~mL})$ and $146.12 \mathrm{~g}$ (equimolar quantity) of L-glutamate were added. The chelation was confirmed by fourier transform infrared spectroscopy (FTIR) analysis for Fe-Glu (Figure 1) and $\mathrm{FeSO}_{4} \cdot 7 \mathrm{H}_{2} \mathrm{O}$ [40] . Foliar application of solutions was done in the evening for the maximum absorption by leaves. To avoid the rain in applied water stress, the whole experimental area was covered with a polythene sheet that was used only when there were the chances of rain. Data were collected for different attributes after three weeks of foliar application of different treatments. Two plants were selected from each row (treatment) in each plot (a total number of eight plants against each treatment) for measuring the shoot and root fresh masses and lengths of shoots and roots. These plant samples were then kept in an electric oven for $48 \mathrm{~h}$ at $65^{\circ} \mathrm{C}$ to obtain their dry masses. The oven-dried root and shoot samples were then used to measure the mineral nutrients. 


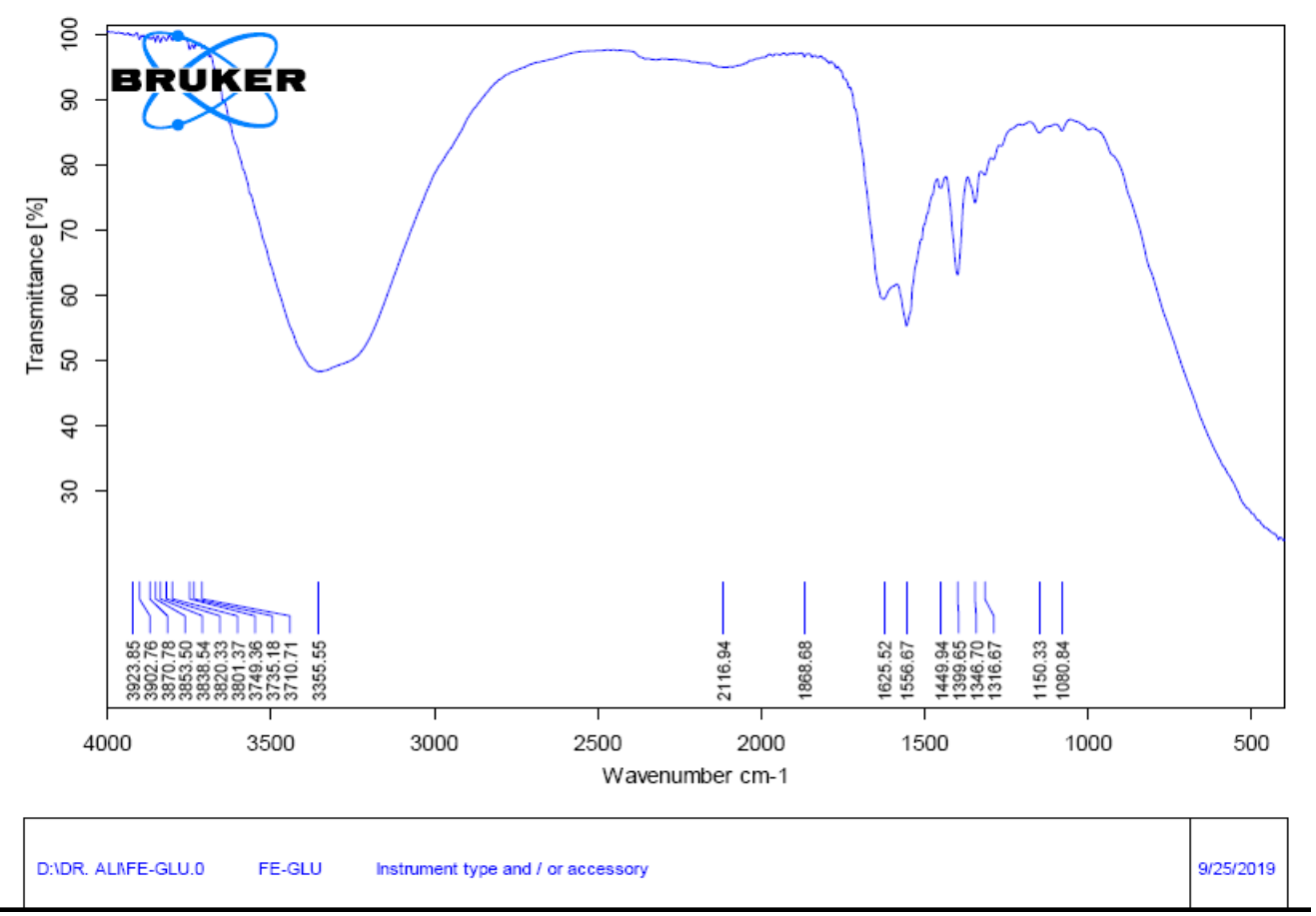

Figure 1. Fourier transform infrared spectroscopy (FTIR) spectra of Fe-Glu used as foliar spray on ajwain plants.

\subsection{Estimation of Leaf Relative Water Content (LRWC)}

Fully developed leaf (3rd from top) from each plant was used for measuring the LRWC. The leaves were excised using scissors and their fresh weights were measured. Leaves were then dipped in distilled water after tagging with permanent marker for $6 \mathrm{~h}$. The leaves were then taken out from water, adsorbed the excess water on their surface and their turgid weights were measured. Then, dry weights of the leaves were measured after oven-drying at $70{ }^{\circ} \mathrm{C}$ for $48 \mathrm{~h}$. Then, the following equation was used for measuring LRWC:

$$
\text { LRWC }(\%)=\frac{\text { Fresh weight of leaf }- \text { Dry weight of leaf }}{\text { Turgid weight of leaf }- \text { Dry weight of leaf }} \times 100
$$

\subsection{Estimation of Leaf Relative Membrane Permeability (LRMP)}

The method described by Yang et al. [41] was followed to find out the LRMP. The known amount $(0.5 \mathrm{~g})$ of excised leaf was cut into small pieces (approximately $1 \mathrm{~cm}$ ) and put in test tubes having $20 \mathrm{~mL}$ of de-ionized $\mathrm{dH}_{2} \mathrm{O}$. After vortexing well for $5 \mathrm{~s}$, the EC of the assayed material was measured and termed as EC0. The test tubes containing leaf material were then kept at $4{ }^{\circ} \mathrm{C}$ for $24 \mathrm{~h}$ and the EC1 was measured. These test tubes containing leaf material were then autoclaved for $30 \mathrm{~min}$ at $120^{\circ} \mathrm{C}$ and assayed the EC2. The LRMP was measured using the equation as follows:

$$
\operatorname{LRMP}(\%)=\frac{\mathrm{EC} 1-\mathrm{EC} 0}{\mathrm{EC} 2-\mathrm{EC} 0} \times 100
$$

\subsection{Estimation of Leaf Chlorophyll (Chl.) and Carotenoid (Car.) Contents}

For the estimation of leaf Chl. $a, b$, total Chl. (T. Chl.) and Chl. $a / b$, the method described by Arnon [42] was followed. The content of Car. was estimated following Kirk and Allen [43]. The extraction of the pigments was done using $80 \%$ acetone. Briefly, fresh leaf material $(0.1 \mathrm{~g})$ was chopped and put in $10 \mathrm{~mL} 80 \%$ acetone for overnight at $4{ }^{\circ} \mathrm{C}$ and the absorbance of the extract was 
read at 663, 645 and $480 \mathrm{~nm}$ using spectrophotometer (Hitachi U-2001, Tokyo, Japan). The quantities were computed using the specific formulas:

$$
\begin{gathered}
\text { Chl. } a=[12.7(\mathrm{OD} 663)-2.69(\mathrm{OD} 645)] \times v / 1000 \times w \\
\text { Chl. } b=[22.9(\mathrm{OD} 645)-4.68(\mathrm{OD} 663)] \times v / 1000 \times w \\
\text { T. Chl. }=[20.2(\mathrm{OD} 645)-8.02(\mathrm{OD} 663)] \times v / w \times 1 / 1000 \\
\text { A Car. }(\mu \mathrm{g} / \mathrm{g} \mathrm{FW})=\text { OD480 }+(0.114 \times \text { OD663) }-(0.638 \times \text { OD645) } \\
\text { Car. }=\text { A Car. } / \text { Em } 100 \% \times 100 \\
\text { Emission }=\text { Em 100\% }=2500
\end{gathered}
$$

$\Delta \mathrm{A}=$ absorbance at respective wavelength

$\mathrm{v}=$ volume of the extract $(\mathrm{mL})$

$\mathrm{w}=$ weight of the fresh leaf tissue $(\mathrm{g})$.

\subsection{Estimation of Leaf Total Phenolic Content (TPC)}

The method ascribed by Julkenen-Titto [44] was followed for the estimation of TPC in fresh leaves. After homogenization of fresh leaf material $(0.05 \mathrm{~g})$ in $5 \mathrm{~mL}$ acetone $(80 \%)$, the homogenate was centrifuged at $10,000 \times g$ for $10 \mathrm{~min}$. Then, $100 \mu \mathrm{L}$ of the obtained supernatant was reacted with Folin-Ciocalteau's phenol reagent $(1 \mathrm{~mL})$. Two $\mathrm{mL}$ of $\mathrm{dH}_{2} \mathrm{O}$ were added to the triturate along with $20 \% \mathrm{Na}_{2} \mathrm{CO}_{3}(5.0 \mathrm{~mL})$ solution. The final volume of the resultant mixture was raised to $10 \mathrm{~mL}$ with $\mathrm{dH}_{2} \mathrm{O}$. After mixing vigorously, the OD of the triturate was read at $750 \mathrm{~nm}$ using a UV-Visible spectrophotometer (IRMECO U2020) (GmbH, Geesthacht, Germany).

\subsection{Estimation of Leaf Total Anthocyanin (T. antho) Content}

For the estimation of leaf anthocyanin content, fresh leaf material $(50 \mathrm{mg})$ was homogenized thoroughly in $1000 \mu \mathrm{L}$ of acidic $\mathrm{MeOH}(1 \% \mathrm{HCl}, w / v)$ in an ice bath. The homogenate was centrifuged at $(14,000 \mathrm{rpm})$ for $5 \mathrm{~min}$ at room temperature. The OD of the supernatant was read at 657 and $530 \mathrm{~nm}$. The equation given below was used for the quantification of T. antho content:

$$
\text { T. antho }=(\text { A530 }-0.25 \times \text { A657 }) \times \mathrm{M}^{-1}
$$

where A657 and A530 is the absorption at specific wavelengths and M is the fresh leaf mass used for the extraction (g).

\subsection{Determination of Leaf Ascorbic Acid (AsA) Content}

The method ascribed by Mukherjee and Choudhuri [45] was followed for the estimation of AsA in fresh leaf. Fresh leaf $(0.25 \mathrm{~g})$ was ground well in $10 \mathrm{~mL}$ trichloroacetic acid (TCA) solution $(6 \%)$. After centrifugation at $10,000 \times g$ for $10 \mathrm{~min}$, the supernatant was reacted with $2 \%$ acidic dinitrophenyl hydrazine $(2 \mathrm{~mL}$ ) solution. Then, 10\% thiourea (one drop) was added to the triturate. The resulted mixture was boiled for $20 \mathrm{~min}$ in a water bath. The mixture was then cooled at $0{ }^{\circ} \mathrm{C}$ and $80 \% \mathrm{H}_{2} \mathrm{SO}_{4}$ $(5 \mathrm{~mL})$ was added in the mixture. The OD of the finally prepared colored material was read at $530 \mathrm{~nm}$. The standard curve was prepared from a range of standard solutions (50-300 ppm) by using pure AsA to estimate the concentration in the leaf samples. 


\subsection{Estimation of Leaf Antioxidant Enzyme Activities and Total Soluble Protein (TSP)}

\subsubsection{Extraction of Antioxidant Enzymes and Total Soluble Proteins (TSP)}

For the extraction of antioxidant enzymes and TSP, fresh leaf material $(0.5 \mathrm{~g})$ was ground in $10 \mathrm{~mL}$ chilled (50 mM phosphate buffer ( $\mathrm{pH} 7.8$ ). The mixture was then centrifuged at 10,000× $g$ for $20 \mathrm{~min}$ at $4{ }^{\circ} \mathrm{C}$. The supernatant so obtained was then used for the estimation of total soluble proteins (TSP) and antioxidative enzymes activities.

\subsubsection{Estimation of TSP}

TSP in the buffer extracts was estimated following the method of Bradford [46]. The absorbance of the triturate was measured at $595 \mathrm{~nm}$ and the quantities of the TSP in samples were computed using a series of protein standards (200-1400 mg/kg) prepared from analytical grade bovine serum albumin (BSA).

\subsubsection{Estimation of Superoxide Dismutase (SOD) Activity}

The method ascribed by Giannopolitis and Ries [47] was employed for the estimation of SOD activity that was measured based on the photochemical reduction inhibition principle of nitroblue tetrazolium (NBT) in light. The reduction inhibition of NBT was measured at $560 \mathrm{~nm}$. Briefly, the prepared mixture for the study was consisted of $1.3 \mu \mathrm{M}$ riboflavin, $13 \mathrm{mM}$ methionine, $50 \mu \mathrm{M}$ NBT, $75 \mathrm{nM}$ EDTA, $50 \mu \mathrm{L}$ enzyme extract and $50 \mathrm{mM}$ phosphate buffer ( $\mathrm{pH}$ 7.8). The mixture was placed in a box, coated internally with aluminum foil under a fluorescent light $(20 \mathrm{~W})$ for 15 min. Then, the absorbance of the reaction mixture was read using a UV-visible spectrophotometer at $560 \mathrm{~nm}$. Along with the reaction mixture prepared using the sample, a reaction mixture without sample was also used as a blank. The SOD activity in samples was estimated as unit/mg protein using the content of TSP.

\subsubsection{Determination of Peroxidase (POD) Activity}

The method ascribed by Chance and Maehly [48] was followed to assay the POD activity in the leaf buffer extract. The basic mechanism behind the estimation of POD activity was based on the oxidation of guaiacol used in reaction mixture. The reaction mixture was comprised $40 \mathrm{mM} \mathrm{H}_{2} \mathrm{O}_{2}$, $20 \mathrm{mM}$ guaiacol, $50 \mathrm{mM}$ phosphate buffer and $100 \mu \mathrm{L}$ leaf phosphate buffer extract. The guaiacol was added last in the reaction solution to start the reaction. The absorbance of the reaction mixture was read with the interval of $20 \mathrm{~s}$, at $470 \mathrm{~nm}$ by setting spectrophotometer in a time scan manner. The change of 0.01 absorbance unit $\mathrm{min}^{-1} \mathrm{mg}^{-1}$ of protein was taken as unit POD activity. The final activity was measured as units/mg protein.

\subsubsection{Determination of Catalase (CAT) and Ascorbate Peroxidase (APX) Activity}

The method ascribed by Chance and Maehly [48] was employed for the estimation of CAT activity in leaf buffer extract. The decrease in the absorbance of the mixture was taken as disappearance of $\mathrm{H}_{2} \mathrm{O}_{2}$ as a basic phenomenon behind the estimation of CAT activity. The reaction mixture comprised $1.9 \mathrm{~mL} \mathrm{H}_{2} \mathrm{O}_{2}, 1 \mathrm{~mL} \mathrm{dH_{2 }} \mathrm{O}$ and $100 \mu \mathrm{L}$ of extract. The APX activity was estimated using the method given by Asada and Takahashi [49]. The activities of these enzymes were estimated by the decrease in absorbance at 240 and $290 \mathrm{~nm}$, respectively, and expressed as units $\mathrm{mg}^{-1}$ protein.

\subsection{Estimation of Total Free Amino Acid (FAA) Content}

The method ascribed by Hamilton and Van-slyke [50] was followed for the estimation of FAA. The same buffer extract as used for the estimation of TSP and enzyme activities was used for the estimation of FAA. The reaction mixture was comprised $1 \mathrm{~mL}$ of $2 \%$ ninhydrin, $1 \mathrm{~mL}$ of $1 \%$ pyridine 
and $1 \mathrm{~mL}$ of the extract (buffer extract). The mixture was then heated in a water bath at $95{ }^{\circ} \mathrm{C}$ for $30 \mathrm{~min}$. After cooling, the final volume was made $50 \mathrm{~mL}$ and the absorbance was read at $570 \mathrm{~nm}$.

Total FAA $=$ Abs $\times \mathrm{v} \times \mathrm{df} / \mathrm{wt}$ of sample $\times 1000$

\subsection{Determination of Leaf Reducing Sugars (RS)}

Leaf RS were estimated following the method ascribed by Wood and Bhat [51]. Fresh leaf sample $(0.5 \mathrm{~g})$ was extracted using $80 \%$ methanol $(5 \mathrm{~mL})$ and centrifuged at $10,000 \times \mathrm{g}$. In a test tube, $4 \mathrm{~mL}$ of the 3, 5-dinitrosalicylic acid reagent (DNS) (prepared by dissolving $1 \mathrm{~g}$ DNS in $20 \mathrm{~mL}$ of $2 \mathrm{M} \mathrm{NaOH}$ and mixed with $30 \mathrm{~g}$ sodium potassium tartrate and diluted to $100 \mathrm{~mL}$ using $\mathrm{dH}_{2} \mathrm{O}$ ) were added to $1 \mathrm{~mL}$ of the sugar solution, and the mixture was then kept in a water bath at $95^{\circ} \mathrm{C}$ for $5 \mathrm{~min}$. Then, the samples were kept in chilled water to rapidly cool the solution and to incubate the resulting material at $25^{\circ} \mathrm{C}$, and the absorbance was then read at $540 \mathrm{~nm}$.

\subsection{Estimation of Total Soluble Sugars (TSS)}

The same leaf extract as used for the estimation of reducing sugars was also used for the determination of TSS. The reaction mixture was comprised $3 \mathrm{~mL}$ of antheron reagent and $0.1 \mathrm{~mL}$ of the extract. The mixture was then put in water bath for $10 \mathrm{~min}$ at $95^{\circ} \mathrm{C}$. The mixture was then cooled in chilled water. The mixture was then incubated for $30 \mathrm{~min}$ at room temperature and the absorbance was read at $625 \mathrm{~nm}$. The final concentration of TSS in samples was estimated using the curve prepared from pure standards.

\subsection{Estimation of Leaf Malondialdehyde (MDA) Content}

Content of MDA was measured in terms of lipid peroxidation using the method given by Cakmak and Horst [52]. Trichloroacetic acid (TCA) method was used for the estimation of MDA content. One g leaf material freshly taken was ground in $10 \mathrm{~mL}$ of TCA $\left(10 \%\right.$ solution prepared in $\left.\mathrm{dH}_{2} \mathrm{O}\right)$. The supernatant $(0.5 \mathrm{~mL})$ as obtained from the homogenized material was mixed with $2 \mathrm{~mL}$ of $0.5 \%$ thiobarbituric acid (TBA), prepared in $20 \%$ TCA. Test tubes having the triturate were kept at $95^{\circ} \mathrm{C}$ for $50 \mathrm{~min}$, and then cooled immediately in chilled water. After centrifugation $(10,000 \times g)$ of mixture for $10 \mathrm{~min}$, the absorbance of colored part was read at 600 and $532 \mathrm{~nm}$. The content of MDA was calculated using the formula:

$$
\operatorname{MDA}(\mathrm{nmol})=\Delta(\mathrm{A} 532 \mathrm{~nm}-\mathrm{A} 600 \mathrm{~nm}) / 1.56 \times 105
$$

Absorption coefficient for the calculation of MDA is $156 \mathrm{mmol}^{-1} \mathrm{~cm}^{-1}$.

\subsection{Estimation of Leaf $\mathrm{H}_{2} \mathrm{O}_{2}$ Content}

Leaf $\mathrm{H}_{2} \mathrm{O}_{2}$ content was determined following the method of Velikova et al. [53]. The fresh leaf sample $(0.5 \mathrm{~g})$ was ground well in $10 \mathrm{~mL}$ TCA $(6 \%)$. To $0.1 \mathrm{~mL}$ of centrifuged TCA extract, $1 \mathrm{~mL}$ of $1 \mathrm{M}$ KI solution was added. The absorbance of resultant mixture was read at $390 \mathrm{~nm}$.

\subsection{Estimation of Different Amino Acids}

\subsubsection{Glutamate (Glu) Determination}

L-glutamate concentrations in phosphate buffer extracted samples were assayed following Beutler and Michal [54]. The basic mechanism was the formation of 2-oxoglutarate by the oxidative deamination in the presence of glutamate dehydrogenase and NAD. Then, the formation of iodonitrotetrazolium chloride (INT) in the presence of diaphorase takes place by oxidative process to a formazan in the presence of NADH. Then the absorbance of INT was read at $492 \mathrm{~nm}$. The samples were deproteinized using $20 \%$ PCA. The reaction mixture was comprised $3.5 \mathrm{~mL}$ sample, $500 \mu \mathrm{L}$ triethanolamine $(57 \mathrm{mM})$, diaphorase (0.14 i.u./mL), NAD (0.38 mM), INT (0.068 mM), potassium phosphate (14 mM, pH 8.6) 
and GDH (14 i.u./mL). The absorbance of mixture was read at $492 \mathrm{~nm}$ against a reagent blank using spectrophotometer.

\subsubsection{Estimation of Leaf Glycine Betaine (GB) Content}

The estimation of GB was ascribed following Grieve and Grattan [55]. Briefly, $1 \mathrm{~g}$ dry leaf material was extracted with $10 \mathrm{~mL} \mathrm{dH_{2 }} \mathrm{O}$ by shaking overnight, followed by the filtration. The reaction mixture was prepared by the addition of $1 \mathrm{~mL}$ of the extract and $1 \mathrm{~mL}$ of $2 \mathrm{~N} \mathrm{HCl}$. Then, this prepared mixture $(0.5 \mathrm{~mL})$ was mixed with $\mathrm{KI}_{3}$ solution $(0.2 \mathrm{~mL})$. Then, to the ice-cooled mixture, dichloromethane $(20 \mathrm{~mL})$ and ice-cooled $\mathrm{H}_{2} \mathrm{O}(2 \mathrm{~mL})$ were added. Then, the mixture was shook well with a continuous passing of air. The absorbance of lower phase was read at $365 \mathrm{~nm}$ and the concentration of GB was calculated using a curve prepared from known standards.

\subsubsection{Estimation of Leaf Proline (Pro) Content}

The method ascribed by Bates et al. [56] was followed for the estimation of proline. Briefly, $0.1 \mathrm{~g}$ of leaf (fresh material) was crushed in $5 \mathrm{~mL}$ of sulfosalicylic acid (3\%). After filtration, $100 \mu \mathrm{L}$ of the extract was mixed well with $20 \mathrm{~mL}$ of $6 \mathrm{M}$ phosphoric acid $(2 \mathrm{~mL}$ each). Then, the mixture was reacted with glacial acetic acid ( $2 \mathrm{~mL}$ of each) and acidic ninhydrin heated the mixture in a water bath for $1 \mathrm{~h}$ at $95^{\circ} \mathrm{C}$. After cooling well, $1 \mathrm{~mL}$ of toluene was mixed with reaction mixture and the optical density of colored phase was read at $520 \mathrm{~nm}$. Proline concentration was measured following the equation:

$$
\text { Proline } \left.\mu \mathrm{mol} \mathrm{g}{ }^{-1} \mathrm{FW}=\mathrm{mL} \text { of toluene } / 115 \mathrm{~g} \times \mu \mathrm{g} \text { proline } \mathrm{mL}^{-1}\right) / \text { sample }(\mathrm{g})
$$

\subsubsection{Estimation of Lysine (Lys) and Methionine (Meth) Contents}

Leaf samples $(0.5 \mathrm{~g})$ were well grinded in a mortar containing $0.1 \% \mathrm{HCl}$. The resulted solution was then mixed with $3 \mathrm{~mL}$ of $50 \%$ glycerol, $1 \mathrm{~mL}$ phosphate buffer and $1 \mathrm{~mL}$ ninhydrin in order to extract lysine. It was then placed in boiling water $\left(100{ }^{\circ} \mathrm{C}\right)$. The absorption was read at $570 \mathrm{~nm}$. Methionine was also extracted by adding $\mathrm{NaOH}(5 \mathrm{~N})$, glycine dihydrate $(50 \%)$, sodium nitroferricyanide dihydrate $(0.1 \%)$ and $\mathrm{HCl}(1: 1)$ to the resulted solution as mentioned above and the absorption was read at $510 \mathrm{~nm}[57]$.

\subsection{Estimation of Oxidized Glutathione (GSH) and Reduced Glutathione (GSSG)}

The contents of oxidized (GSSG) and reduced (GSH) glutathione in ajwain leaves were assayed following Griffith [58]. Briefly, fresh leaf material $(250 \mathrm{mg})$ was ground well in $0.1 \mathrm{M} \mathrm{HCl}(2 \mathrm{~mL})$ containing EDTA $(1 \mathrm{mM})$. Then, the supernatant was obtained by the centrifugation of extract at $12,000 \times g$ for $15 \mathrm{~min}$ at $4{ }^{\circ} \mathrm{C}$. The reaction mixture was prepared by adding $200 \mu \mathrm{L}$ phosphate buffer $(125 \mu \mathrm{M})$ having $6.3 \mathrm{mM}$ EDTA (pH 7.5), $100 \mu \mathrm{L}$ DTNB $(6.0 \mathrm{mM}), 200 \mu \mathrm{L}$ extract and $500 \mu \mathrm{L}$ NADPH $(0.3 \mathrm{mM})$. The absorbance of mixture was read at $412 \mathrm{~nm}$.

\subsection{Determination of Yield Attributes}

At maturity, different yield attributes such as 100 seed weight, number of umbels (NOU), and seed yield per plant were estimated manually. At physiological maturity, 10 plants from each replicate were selected for the estimation of yield attributes. Number of umbels were counted from each plant and separated from the plant. The seeds were then separated by hands by slight rubbing. Then, 100 seeds were separated and weighed. Seed yield per plant was estimated by weighing the obtained seeds from each selected plant.

\subsection{Determination of Nutrients in Roots and Shoots}

Powdered samples were digested using sulphuric acid as ascribed by Wolf [59]. Contents of different cations like $\mathrm{Ca}^{+}, \mathrm{K}^{+}, \mathrm{Mg}^{2+}$ and $\mathrm{Fe}^{2+}$ were determined by AAS (Hitachi, Model 7JO-8024, 
Tokyo, Japan). Phosphorus content was determined spectrophotometrically using Barton's reagent. The content of $(\mathrm{N})$ was determined using the method as ascribed by Bremner and Keeney [60] from the digested material.

\subsection{Statistical Analysis}

Data recorded for varying studied parameters were analyzed statistically using Co-STAT version 6.3 (developed by Cohort Software Berkley, CA, USA) to find out significant difference among the treatments. To find out the significant difference among mean values of different treatments both under stressed and non-stressed conditions, least significance difference (LSD) test was employed at $5 \%$ level of significance. Correlations and PCA analysis of the studied parameters were performed using the XLSTAT software and the significance among the generated values of each attribute was found using the Spearman's correlation table.

\section{Results}

Water stress adversely affected different morphological and growth attributes such as root length (RL), shoot length (SL), shoot fresh weight (SFW), shoot dry weight (SDW), root fresh weight (RFW), and root dry weight (RDW) of ajwain plants (Figure 2; Table 1). Exogenously-applied Fe-Glu and $\mathrm{FeSO}_{4}$ as foliar spray was found effective in improving all studied morphological and growth attributes. More improvement in these morphological and growth attributes was due to foliar spray with both levels of Fe-Glu in comparison with $\mathrm{FeSO}_{4}$. Furthermore, both levels of Fe-Glu were found equally effective in enhancing plant performance and reducing the deleterious effects of water stress on studied growth attributes. Similarly, both levels of $\mathrm{FeSO}_{4}$ were also found equally effective but the effectiveness was less than Fe-Glu.

(a) Non-Stressed plants

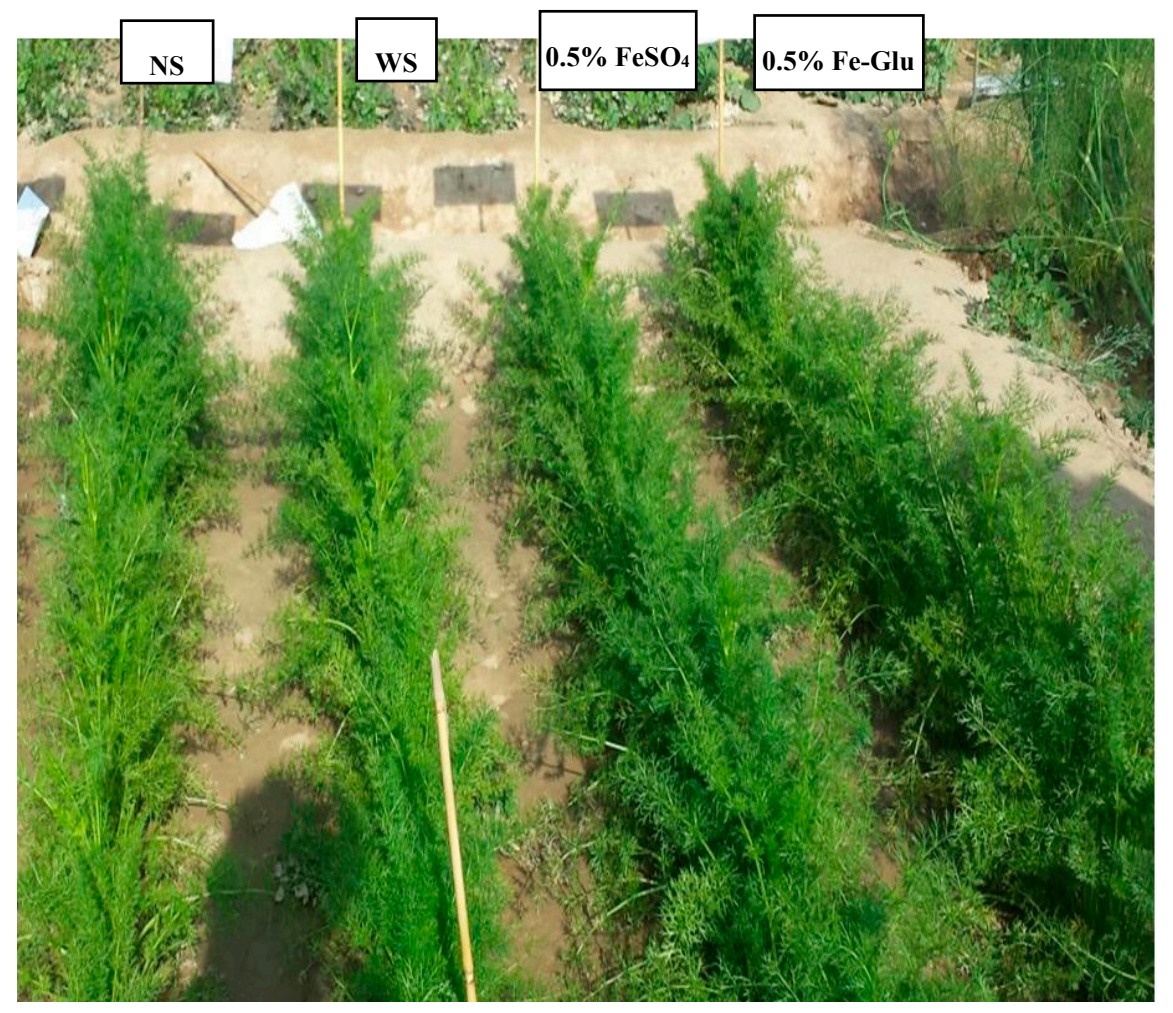

Figure 2. Cont. 
(b) Water stressed plants

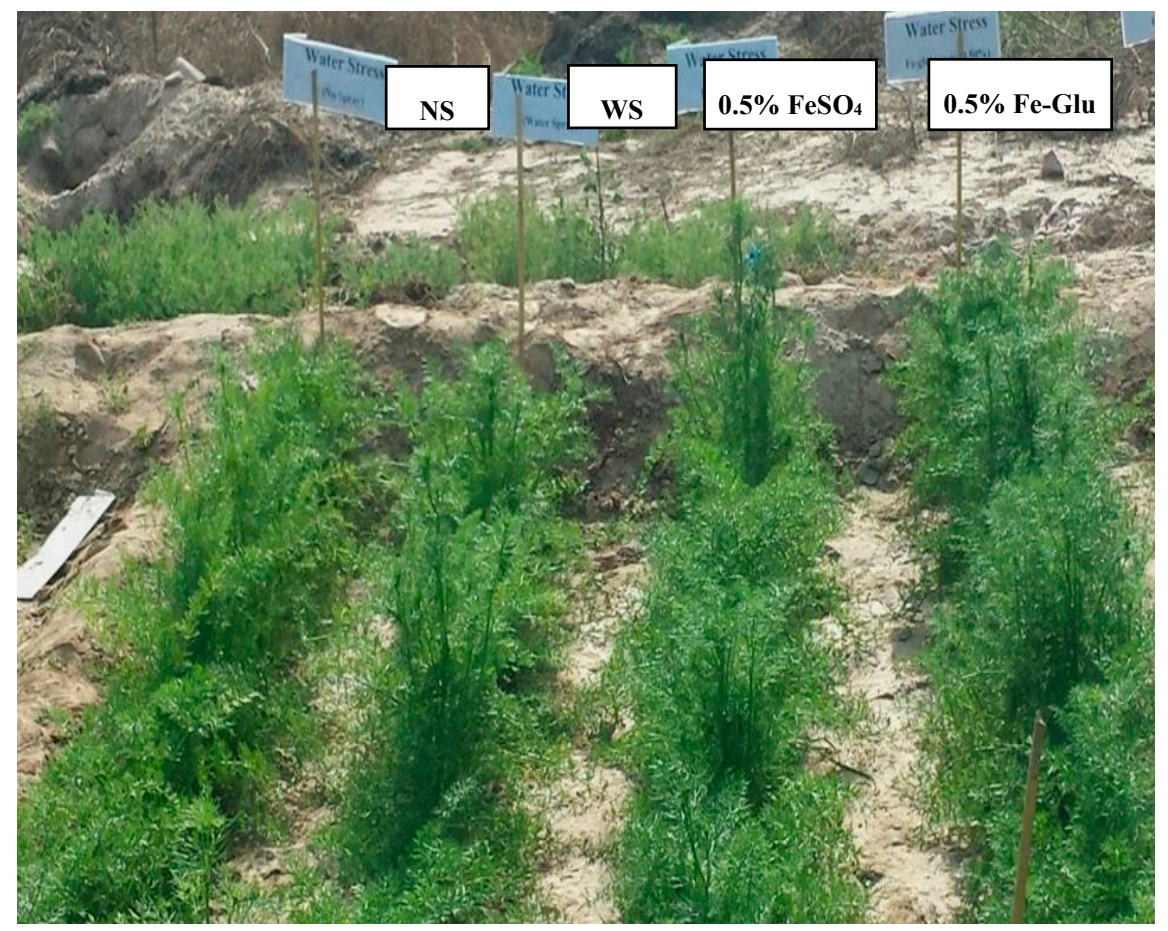

Figure 2. Growing ajwain plants under non-stressed (a) and water-stressed conditions (b) -supplied with Fe-Glu and $\mathrm{FeSO}_{4}$. Here, NS and WS = No Spray and Water Spray, respectively.

A significant reduction due to imposition of water stress was recorded in number of umbels (NOU), 100 seed weight and seed yield per plant of ajwain as presented in Table 1. Foliar spray of both levels of Fe-Glu and $\mathrm{FeSO}_{4}$ were found helpful in enhancing plant performance under water stress and non-stressed conditions. They further reduced the negative impact of water shortage on these yield parameters of ajwain plants but both the levels of Fe-Glu were found more effective. More increase regarding yield per plant under water stress was found due to foliar spray with Fe-Glu (26.17 and $36.40 \%$ increase at 0.25 and $0.50 \%$ levels, respectively) in comparison with $\mathrm{FeSO}_{4}$ (5.32 and $4.91 \%$ increase at 0.25 and $0.50 \%$ levels, respectively). Similarly, under non-stressed conditions, this increase in seed yield was more in plants sprayed with Fe-Glu (20.61 and $18.62 \%$ increase at 0.25 and $0.50 \%$ levels, respectively) as compared with plants supplied with $\mathrm{FeSO}_{4}$ (6.76 and 8.78\% increase at 0.25 and $0.50 \%$ levels, respectively). Both levels of Fe-Glu were found more effective in comparison with $\mathrm{FeSO}_{4}$ in reducing the deleterious effects of water deficiency on these yield attributes of ajwain plants (Table 1).

Leaf Chl. $a$, Chl. $b$, Car. and total Chl. contents of ajwain plants increased significantly when grown under water deficit conditions. Exogenous application of only Fe-Glu as foliar spray at both levels significantly improved the leaf Chl. $a, b$ and total Chl. content, both under stressed and non-stressed conditions, but in the case of leaf Chl. $a$, both levels of $\mathrm{FeSO}_{4}$ were also found effective. However, in the case of leaf Car. foliar spray, both levels of $\mathrm{FeSO}_{4}$ and $\mathrm{Fe}-\mathrm{Glu}$ significantly improved the leaf Car. both under stressed and non-stressed conditions. Under water-stressed conditions, both levels of $\mathrm{FeSO}_{4}$ or Fe-Glu were found equally effective but in the case of non-stressed conditions, this increase in leaf Car. was slightly more higher of Fe-Glu. Moreover, a non-significant effect of water stress was found on leaf Chl. $a / b$. Foliar spray of both levels of $\mathrm{FeSO}_{4}$ and Fe-Glu significantly improved the leaf $\mathrm{Chl}$. $a / b$ but this increasing effect was found only in non-stressed plants and the higher level of $\mathrm{FeSO}_{4}$ was more effective, but under water deficit conditions, a non-significant decrease in leaf Chl. $a / b$ was found due to foliar spray of Fe-Glu or $\mathrm{FeSO}_{4}$ (Table 2). 
Table 1. SL, RL, SFW, RFW, SDW, RDW, NOU, seed yield per plant, and 100 seed weight of water-stressed and non-stressed ajwain (Trachyspermum ammi L.) plants exogenously applied with different levels of Fe-Glu and $\mathrm{FeSO}_{4}$ as foliar spray at vegetative stage (mean $\pm \mathrm{SE} ; n=3$ ).

\begin{tabular}{|c|c|c|c|c|c|c|c|c|c|c|}
\hline \multirow{2}{*}{ Treatment } & \multicolumn{2}{|c|}{ SL (cm) } & \multicolumn{2}{|c|}{ RL (cm) } & \multicolumn{2}{|c|}{ SFW (g/plant) } & \multicolumn{2}{|c|}{ RFW (g plant ${ }^{-1}$ ) } & \multicolumn{2}{|c|}{ SDW (g plant ${ }^{-1}$ ) } \\
\hline & Non-Stressed & Water-Stressed & Non-Stressed & Water-Stressed & Non-Stressed & Water-Stressed & Non-Stressed & Water-Stressed & Non-Stressed & Water-Stressed \\
\hline NS & $51.2 \pm 3.6^{b}$ & $25.9 \pm 1.6^{c}$ & $8.7 \pm 0.4^{\mathrm{b}}$ & $5.6 \pm 0.2^{c}$ & $59.0 \pm 2.6^{\text {ba }}$ & $32.6 \pm 1.1^{\mathrm{b}}$ & $2.6 \pm 0.2^{\mathrm{a}}$ & $1.2 \pm 0.1^{\mathrm{b}}$ & $4.3 \pm 0.3^{\mathrm{b}}$ & $2.1 \pm 0.2^{b}$ \\
\hline WS & $51.1 \pm 1.5^{b}$ & $26.6 \pm 2.1^{c}$ & $8.4 \pm 0.4^{b}$ & $5.9 \pm 0.4^{b c}$ & $54.8 \pm 2.4^{b}$ & $34.7 \pm 1.8^{b}$ & $2.7 \pm 0.1^{\mathrm{a}}$ & $1.3 \pm 0.2^{b}$ & $4.4 \pm 0.2^{b}$ & $2.2 \pm 0.2^{b}$ \\
\hline $0.25 \%$ Fe-Glu & $57.0 \pm 1.2^{\mathrm{a}}$ & $33.1 \pm 2.8^{\mathrm{ab}}$ & $9.6 \pm 0.3^{\mathrm{a}}$ & $7.9 \pm 0.4^{\mathrm{a}}$ & $60.0 \pm 3.4^{\mathrm{a}}$ & $45.6 \pm 3.0^{\mathrm{a}}$ & $2.8 \pm 0.2^{\mathrm{a}}$ & $1.7 \pm 0.2^{\mathrm{a}}$ & $5.1 \pm 0.3^{\mathrm{a}}$ & $3.3 \pm 0.2^{\mathrm{a}}$ \\
\hline $0.50 \%$ Fe-Glu & $57.1 \pm 2.1^{\mathrm{a}}$ & $35.4 \pm 0.8^{\mathrm{a}}$ & $9.9 \pm 0.3^{\mathrm{a}}$ & $8.0 \pm 0.6^{\mathrm{a}}$ & $65.6 \pm 3.2^{\mathrm{a}}$ & $43.9 \pm 3.2^{\mathrm{a}}$ & $2.8 \pm 0.1^{\mathrm{a}}$ & $1.6 \pm 0.1^{\mathrm{a}}$ & $5.2 \pm 0.1^{\mathrm{a}}$ & $3.3 \pm 0.3^{\mathrm{a}}$ \\
\hline $0.25 \% \mathrm{FeSO}_{4}$ & $54.0 \pm 0.9^{a b}$ & $30.0 \pm 1.7^{b}$ & $9.5 \pm 0.5^{\mathrm{a}}$ & $6.7 \pm 0.6^{b}$ & $61.5 \pm 5.6^{\mathrm{a}}$ & $38.4 \pm 2.7 \mathrm{ab}$ & $2.7 \pm 0.2^{\mathrm{a}}$ & $1.4 \pm 0.1^{\mathrm{a}}$ & $4.8 \pm 0.4^{\mathrm{ab}}$ & $2.4 \pm 0.3^{b}$ \\
\hline $0.5 \% \mathrm{FeSO}_{4}$ & $52.0 \pm 3.1^{\mathrm{b}}$ & $31.0 \pm 1.2^{b}$ & $9.2 \pm 0.3^{\mathrm{a}}$ & $6.6 \pm 0.5^{b}$ & $67.1 \pm 1.5^{\mathrm{a}}$ & $39.6 \pm 2.4^{\mathrm{ab}}$ & $2.8 \pm 0.1^{\mathrm{a}}$ & $1.4 \pm 0.1^{\mathrm{a}}$ & $4.8 \pm 0.2^{\mathrm{ab}}$ & $2.3 \pm 0.1^{b}$ \\
\hline LSD at $5 \%$ level & & & & 0 & & 6 & & & & 5 \\
\hline \multirow{2}{*}{ Treatment } & \multicolumn{2}{|c|}{ RDW (g plant ${ }^{-1}$ ) } & \multicolumn{2}{|c|}{ NOU/plant } & \multicolumn{2}{|c|}{ Seed yield per plant (g) } & \multicolumn{2}{|c|}{100 seed weight (g) } & & \\
\hline & Non-stressed & Water-stressed & Non-stressed & Water-stressed & Non-stressed & Water-stressed & Non-stressed & Water-stressed & & \\
\hline NS & $0.23 \pm 0.02^{c}$ & $0.13 \pm 0.01^{\mathrm{b}}$ & $12.3 \pm 0.9^{b}$ & $8.7 \pm 0.9^{b}$ & $8.4 \pm 0.3^{\mathrm{c}}$ & $4.9 \pm 0.1^{\mathrm{b}}$ & $0.30 \pm 0.01 \mathrm{ab}$ & $0.22 \pm 0.01^{\mathrm{b}}$ & & \\
\hline WS & $0.24 \pm 0.01^{c}$ & $0.14 \pm 0.01^{b}$ & $12.7 \pm 0.7 \mathrm{ab}$ & $9.0 \pm 0.9^{b}$ & $8.8 \pm 0.2^{\mathrm{bc}}$ & $5.0 \pm 0.3^{b}$ & $0.30 \pm 0.01 \mathrm{ab}$ & $0.21 \pm 0.01^{b}$ & & \\
\hline $0.25 \%$ Fe-Glu & $0.29 \pm 0.01 \mathrm{ab}$ & $0.17 \pm 0.02^{\mathrm{a}}$ & $13.0 \pm 0.5^{\mathrm{a}}$ & $10.7 \pm 0.9^{\mathrm{a}}$ & $10.2 \pm 0.2^{\mathrm{a}}$ & $6.2 \pm 0.2^{\mathrm{a}}$ & $0.32 \pm 0.02^{\mathrm{a}}$ & $0.26 \pm 0.01^{\mathrm{a}}$ & & \\
\hline $0.50 \%$ Fe-Glu & $0.30 \pm 0.02^{\mathrm{a}}$ & $0.16 \pm 0.02 \mathrm{ab}$ & $13.5 \pm 0.6^{\mathrm{a}}$ & $10.3 \pm 0.3 \mathrm{ab}$ & $10.0 \pm 0.6^{\mathrm{a}}$ & $6.7 \pm 0.2^{\mathrm{a}}$ & $0.32 \pm 0.02^{\mathrm{a}}$ & $0.27 \pm 0.02^{\mathrm{a}}$ & & \\
\hline $0.25 \% \mathrm{FeSO}_{4}$ & $0.26 \pm 0.01 b^{c}$ & $0.14 \pm 0.01^{b}$ & $13.7 \pm 0.9^{\mathrm{a}}$ & $9.3 \pm 0.5^{b}$ & $9.0 \pm 0.3^{b}$ & $5.2 \pm 0.3^{b}$ & $0.29 \pm 0.01^{b}$ & $0.22 \pm 0.01^{b}$ & & \\
\hline $0.5 \% \mathrm{FeSO}_{4}$ & $0.27 \pm 0.02^{\mathrm{b}}$ & $0.15 \pm 0.01 \mathrm{ab}$ & $13.5 \pm 0.6^{\mathrm{a}}$ & $9.7 \pm 0.3^{a b}$ & $9.2 \pm 0.2^{b}$ & $5.1 \pm 0.1^{b}$ & $0.30 \pm 0.02^{\mathrm{ab}}$ & $0.22 \pm 0.02^{b}$ & & \\
\hline LSD at $5 \%$ level & \multicolumn{2}{|c|}{0.02} & \multicolumn{2}{|c|}{1.24} & \multicolumn{2}{|c|}{0.50} & \multicolumn{2}{|c|}{0.02} & & \\
\hline
\end{tabular}

Means with the same alphabetical letters in superscript in a column are not significantly different. $\mathrm{SL}=$ shoot length; RL = root length; $\mathrm{SFW}=$ shoot fresh weight; RFW = root fresh weight; $\mathrm{SDW}=$ shoot dry weight; RDW = root dry weight; NOU = number of umbels. 
Table 2. Leaf Chl. $a, b$, T. Chl., Car., T. antho, TSS, RS contents and Chl. a/b, of water-stressed and non-stressed ajwain (Trachyspermum ammi L.) plants exogenously applied with different levels of Fe-Glu and $\mathrm{FeSO}_{4}$ as foliar spray at vegetative stage (mean $\pm \mathrm{SE} ; n=3$ ).

\begin{tabular}{|c|c|c|c|c|c|c|c|c|}
\hline \multirow{2}{*}{ Treatment } & \multicolumn{2}{|c|}{ Chl. $a\left(\mathrm{mg} \mathrm{g}^{-1} \mathrm{FW}\right)$} & \multicolumn{2}{|c|}{ Chl. $b\left(\mathrm{mg} \mathrm{g}^{-1} \mathrm{FW}\right)$} & \multicolumn{2}{|c|}{ Chl. $a / b$} & \multicolumn{2}{|c|}{ T. Chl. (mg g $\left.{ }^{-1} \mathrm{FW}\right)$} \\
\hline & Non-Stressed & Water-Stressed & Non-Stressed & Water-Stressed & Non-Stressed & Water-Stressed & Non-Stressed & Water-Stressed \\
\hline NS & $2.1 \pm 0.1^{\mathrm{d}}$ & $2.9 \pm 0.14^{c}$ & $0.35 \pm 0.01^{b}$ & $0.51 \pm 0.01^{\mathrm{b}}$ & $5.6 \pm 0.07^{b}$ & $5.6 \pm 0.09^{a}$ & $2.4 \pm 0.04^{\mathrm{d}}$ & $3.4 \pm 0.15^{\mathrm{b}}$ \\
\hline WS & $2.1 \pm 0.2^{d}$ & $2.8 \pm 0.16^{c}$ & $0.36 \pm 0.02^{b}$ & $0.53 \pm 0.02^{b}$ & $5.7 \pm 0.10^{a b}$ & $5.2 \pm 0.04^{\mathrm{a}}$ & $2.4 \pm 0.18^{\mathrm{d}}$ & $3.3 \pm 0.18^{b}$ \\
\hline $0.25 \%$ Fe-Glu & $2.5 \pm 0.2^{\mathrm{a}}$ & $3.2 \pm 0.09^{b}$ & $0.43 \pm 0.02^{\mathrm{a}}$ & $0.62 \pm 0.04^{\mathrm{a}}$ & $5.8 \pm 0.15^{\mathrm{ab}}$ & $5.1 \pm 0.37^{\mathrm{a}}$ & $2.9 \pm 0.18^{a b}$ & $3.8 \pm 0.13^{\mathrm{a}}$ \\
\hline $0.50 \%$ Fe-Glu & $2.5 \pm 0.2^{\mathrm{a}}$ & $3.4 \pm 0.11^{\mathrm{a}}$ & $0.43 \pm 0.07^{\mathrm{a}}$ & $0.67 \pm 0.05^{\mathrm{a}}$ & $5.9 \pm 0.23^{a b}$ & $5.0 \pm 0.16^{\mathrm{a}}$ & $3.0 \pm 0.21^{\mathrm{a}}$ & $4.0 \pm 0.15^{\mathrm{a}}$ \\
\hline $0.25 \% \mathrm{FeSO}_{4}$ & $2.2 \pm 0.2^{\mathrm{cd}}$ & $2.8 \pm 0.15^{c}$ & $0.37 \pm 0.04^{b}$ & $0.53 \pm 0.02^{b}$ & $6.0 \pm 0.12^{a b}$ & $5.3 \pm 0.04^{\mathrm{a}}$ & $2.6 \pm 0.22^{\mathrm{cd}}$ & $3.3 \pm 0.17^{b}$ \\
\hline $0.5 \% \mathrm{FeSO}_{4}$ & $2.3 \pm 0.1 \mathrm{bc}$ & $2.9 \pm 0.14^{\mathrm{c}}$ & $0.36 \pm 0.05^{b}$ & $0.55 \pm 0.03^{b}$ & $6.4 \pm 0.15^{\mathrm{a}}$ & $5.3 \pm 0.17^{a}$ & $2.7 \pm 0.18^{b c}$ & $3.5 \pm 0.17^{b}$ \\
\hline LSD at $5 \%$ level & & & & & & & & \\
\hline \multirow{2}{*}{ Treatment } & \multicolumn{2}{|c|}{ Car. (mg $100 \mathrm{~g}^{-1} \mathrm{FW}$ ) } & \multicolumn{2}{|c|}{ T. antho (mg kg $\left.{ }^{-1} \mathrm{FW}\right)$} & \multicolumn{2}{|c|}{ TSS (mg g ${ }^{-1}$ FW) } & \multicolumn{2}{|c|}{ RS (mg $\left.100 g^{-1} \mathrm{FW}\right)$} \\
\hline & Non-stressed & Water-stressed & Non-stressed & Water-stressed & Non-stressed & Water-stressed & Non-stressed & Water-stressed \\
\hline NS & $1.8 \pm 0.09^{b}$ & $3.3 \pm 0.17^{b}$ & $3.9 \pm 0.36^{b c}$ & $9.6 \pm 0.63^{b}$ & $56.9 \pm 2.15^{\mathrm{d}}$ & $87.9 \pm 2.38^{c}$ & $5.9 \pm 0.07^{b}$ & $8.1 \pm 0.09^{c}$ \\
\hline WS & $1.8 \pm 0.17^{b}$ & $3.4 \pm 0.26^{b}$ & $3.8 \pm 0.28^{c}$ & $10.4 \pm 0.53^{b}$ & $60.9 \pm 1.75^{\mathrm{d}}$ & $95.8 \pm 1.98^{b}$ & $6.2 \pm 0.09^{b}$ & $8.3 \pm 0.11^{c}$ \\
\hline $0.25 \%$ Fe-Glu & $2.7 \pm 0.16^{\mathrm{a}}$ & $4.7 \pm 0.27^{\mathrm{a}}$ & $6.2 \pm 0.49^{a b}$ & $13.9 \pm 0.43^{a}$ & $73.0 \pm 1.65^{a b}$ & $110.7 \pm 1.51^{a}$ & $7.6 \pm 0.11^{a}$ & $11.0 \pm 0.12^{\mathrm{a}}$ \\
\hline $0.50 \%$ Fe-Glu & $2.6 \pm 0.18^{a b}$ & $4.6 \pm 0.28^{a}$ & $7.2 \pm 0.34^{\mathrm{a}}$ & $15.3 \pm 0.53^{a}$ & $75.0 \pm 2.35^{\mathrm{a}}$ & $113.0 \pm 2.87^{a}$ & $7.9 \pm 0.08^{a}$ & $11.5 \pm 0.09^{a}$ \\
\hline $0.25 \% \mathrm{FeSO}_{4}$ & $2.2 \pm 0.27 \mathrm{ab}$ & $4.7 \pm 0.18^{\mathrm{a}}$ & $5.0 \pm 0.30^{a b c}$ & $10.3 \pm 0.75^{b}$ & $69.3 \pm 1.89 b c$ & $90.7 \pm 2.14^{c}$ & $6.2 \pm 0.09^{b}$ & $9.5 \pm 0.07^{b}$ \\
\hline $0.5 \% \mathrm{FeSO}_{4}$ & $2.3 \pm 0.26^{\mathrm{ab}}$ & $4.9 \pm 0.17^{\mathrm{a}}$ & $4.8 \pm 0.39 b c$ & $9.7 \pm 0.54^{b}$ & $66.5 \pm 2.32^{c}$ & $97.0 \pm 1.89^{b}$ & $6.6 \pm 0.10^{b}$ & $10.0 \pm 0.08^{b}$ \\
\hline LSD at $5 \%$ level & \multicolumn{2}{|c|}{0.86} & \multicolumn{2}{|c|}{2.4} & \multicolumn{2}{|c|}{4.15} & \multicolumn{2}{|c|}{0.55} \\
\hline
\end{tabular}

Means with the same alphabetical letters in superscript in a column are not significantly different. Chl. $a=$ chlorophyll $a$; Chl. $b=$ chlorophyll $b$; Chl.a/b $=$ chlorophyll a/b ratio; T. Chl. $=$ total chlorophyll; Car. $=$ Carotenoids; $\mathrm{T}$ antho $=$ total anthocyanin; $\mathrm{RS}=$ reducing sugars; $\mathrm{TSS}=$ total soluble sugars. 
Imposition of water stress significantly increased the leaf T. antho, TSS and RS contents of ajwain plants. Exogenous application of $\mathrm{FeSO}_{4}$ and Fe-Glu as foliar spray further significantly improved the contents of T. antho, TSS and RS, both under stressed and non-stressed conditions. However, foliar spray of Fe-Glu was found comparatively more effective (Table 2).

Imposition of water stress significantly improved the contents of leaf Asp, Glu, Meth, GB and Pro in leaf of ajwain plants but this increase was not found in the case of Lys content, which remained unaffected. Foliar applied at both levels of only the Fe-Glu further improved the accumulation of Glu, Meth, GB and Pro, except to that of leaf Meth and Lys. In the case of Asp, foliar spray of both of the $\mathrm{FeSO}_{4}$ and $\mathrm{Fe}$-Asp were found effective in increasing the content but slightly more was due to higher level of Fe-Asp. In the case of Lys, more increase was found in plants sprayed with higher level of $\mathrm{FeSO}_{4}$. Furthermore, in the case of leaf GB content, slightly more accumulation was found due to foliar spray of lower level (0.25\%) of Fe-Glu (Table 3).

Uptake of N, P, K and Fe in root and shoot of ajwain pants decreased significantly due to imposition of water stress (Table 4). Foliar-applied Fe-Glu and $\mathrm{FeSO}_{4}$ significantly reduced the deleterious effects of water stress on the uptake of N, P, K and Fe in both root and shoot. Both levels of $\mathrm{FeSO}_{4}$ and Fe-Glu were found equally effective in improving the uptake of $\mathrm{N}, \mathrm{P}$ and $\mathrm{K}$ in shoot and root under limited water supply except to that of root $\mathrm{P}$ and Fe content in root and shoot that was significantly higher in water-stressed ajwain plants-supplied with both levels of Fe-Glu as compared with $\mathrm{FeSO}_{4}$. Root and shoot $\mathrm{Ca}$ and $\mathrm{Mg}$ contents also reduced significantly due to water stress. However, an improvement in the uptake of $\mathrm{Ca}$ and $\mathrm{Mg}$ in root and shoot was recorded in water-stressed ajwain plants-supplied with both levels of Fe-Glu only, and the effect was the same at both the levels of Fe-Glu.

A significant reduction was recorded in LRWC, TSP, as well as the content of TPC of ajwain plants due to imposition of water stress. Foliar application of Fe-Glu was found effective in reducing the negative impacts of water deficit conditions on these attributes. Both levels of Fe-Glu were found more helpful in increasing the LRWC, TSP and TPC content in comparison to $\mathrm{FeSO}_{4}$ of water-stressed ajwain plants (Figure 3).

Significant increase in LRMP, leaf $\mathrm{H}_{2} \mathrm{O}_{2}$ and MDA accumulation was recorded in ajwain plants when grown under water stress. Foliar applied at both levels of $\mathrm{FeSO}_{4}$ and Fe-glu significantly reduced the leaf LRMP, $\mathrm{H}_{2} \mathrm{O}_{2}$ and MDA accumulation in water-stressed ajwain plants. Both levels of Fe-Glu were found more effective in reducing these parameters in comparison to both levels of $\mathrm{FeSO}_{4}$ under limited water supply. In the case of $\mathrm{H}_{2} \mathrm{O}_{2}$, the higher levels of both Fe-Glu and $\mathrm{FeSO}_{4}$ were found more effective, but in the case of LRMP, higher level of Fe-Glu was better in this regard, while the opposite was true for $\mathrm{FeSO}_{4}$ (Figure 3).

Imposition of stress significantly increased the leaf AsA accumulation in ajwain plants. Treating plants with different levels of Fe-Glu was only found effective in improving the accumulation of leaf AsA in water-stressed ajwain plants. Both levels of Fe-Glu were found equally effective in further improving the leaf AsA content. However, under non-stress conditions, foliar spray of both $\mathrm{FeSO}_{4}$ and Fe-Glu increased the accumulation of AsA and more increment was found in ajwain plants — supplied with both levels of Fe-Glu in comparison with $\mathrm{FeSO}_{4}$ (Figure 3).

Accumulation of leaf FFA increased significantly in water-stressed ajwain plants. Foliar-applied Fe-Glu and $\mathrm{FeSO}_{4}$ significantly reduced the accumulation of FAA in water-stressed ajwain plants. Both levels of $\mathrm{FeSO}_{4}$ and Fe-Glu were found equally effective in reducing the accumulation of FAA in water-stressed ajwain plants.

Activities of POD and SOD and the contents of GSG and GSSG increased significantly in water-stressed ajwain plants. Foliar application of both levels of $\mathrm{FeSO}_{4}$ and Fe-Glu further improved the POD and SOD activities, and GSG and GSSG accumulation. More increase in the activities of SOD and POD, and contents of GSG and GSSG were found in plants treated with both levels of Fe-Glu in comparison with $\mathrm{FeSO}_{4}$. The higher levels were found more effective except in the case of GSSG where both levels of $\mathrm{FeSO}_{4}$ and Fe-Glu were found equally effective in increasing the content of GSSG (Figure 4). 
Table 3. Asp, Lys, Meth, Glu, Pro and GB contents of water-stressed and non-stressed ajwain (Trachyspermum ammi L.) plants exogenously applied with different levels of Fe-Glu and $\mathrm{FeSO}_{4}$ as foliar spray at vegetative stage (mean $\pm \mathrm{SE} ; n=3$ ).

\begin{tabular}{|c|c|c|c|c|c|c|}
\hline \multirow{2}{*}{ Treatment } & \multicolumn{2}{|c|}{$\operatorname{Asp}\left(\mathrm{mg} \mathrm{kg}^{-1} \mathrm{FW}\right)$} & \multicolumn{2}{|c|}{ Lys (mg kg $\left.{ }^{-1} \mathrm{FW}\right)$} & \multicolumn{2}{|c|}{ Meth $\left(\mathrm{mg} \mathrm{kg}^{-1} \mathrm{FW}\right)$} \\
\hline & Non-Stressed & Water-Stressed & Non-Stressed & Water-Stressed & Non-Stressed & Water-Stressed \\
\hline NS & $4.14 \pm 0.02^{\mathrm{a}}$ & $8.3 \pm 0.33^{c}$ & $36.5 \pm 0.50^{\mathrm{a}}$ & $36.5 \pm 0.76^{\mathrm{ab}}$ & $8.2 \pm 0.20^{a}$ & $13.2 \pm 0.35^{b}$ \\
\hline WS & $4.07 \pm 0.02^{\mathrm{a}}$ & $8.0 \pm 0.58^{c}$ & $34.3 \pm 0.67^{\mathrm{a}}$ & $35.5 \pm 1.80^{b}$ & $7.9 \pm 0.43^{a}$ & $13.6 \pm 0.35^{b}$ \\
\hline $0.25 \%$ Fe-Glu & $4.07 \pm 0.06^{\mathrm{a}}$ & $11.2 \pm 0.52^{b}$ & $37.2 \pm 1.17^{\mathrm{a}}$ & $37.4 \pm 0.83^{a b}$ & $8.4 \pm 0.38^{a}$ & $16.5 \pm 0.57^{a}$ \\
\hline $0.50 \%$ Fe-Glu & $4.10 \pm 0.08^{a}$ & $13.2 \pm 0.50^{\mathrm{a}}$ & $37.3 \pm 1.45^{\mathrm{a}}$ & $37.5 \pm 1.04^{\mathrm{ab}}$ & $9.1 \pm 0.19^{\mathrm{a}}$ & $16.6 \pm 0.23^{a}$ \\
\hline $0.25 \% \mathrm{FeSO}_{4}$ & $4.07 \pm 0.04^{\mathrm{a}}$ & $11.8 \pm 0.29^{b}$ & $33.7 \pm 2.15^{\mathrm{a}}$ & $38.0 \pm 1.53^{\mathrm{ab}}$ & $8.1 \pm 0.20^{a}$ & $13.2 \pm 0.35^{b}$ \\
\hline $0.5 \% \mathrm{FeSO}_{4}$ & $4.21 \pm 0.15^{\mathrm{a}}$ & $11.6 \pm 0.06^{b}$ & $36.8 \pm 1.30^{\mathrm{a}}$ & $39.5 \pm 0.50^{\mathrm{a}}$ & $8.7 \pm 0.25^{\mathrm{a}}$ & $13.9 \pm 0.24^{b}$ \\
\hline LSD at $5 \%$ level & & & & & & \\
\hline \multirow{2}{*}{ Treatment } & \multicolumn{2}{|c|}{ Glu (mg kg $\left.{ }^{-1} \mathrm{FW}\right)$} & \multicolumn{2}{|c|}{ Pro $\left(\mu \mathrm{mol} \mathrm{g}{ }^{-1} F W\right)$} & \multicolumn{2}{|c|}{$\mathrm{GB}\left(\mu \mathrm{g} \mathrm{g}^{-1} \mathrm{FW}\right)$} \\
\hline & Non-stressed & Water-stressed & Non-stressed & Water-stressed & Non-stressed & Water-stressed \\
\hline NS & $16.5 \pm 0.40^{a}$ & $26.4 \pm 0.69^{b}$ & $14.1 \pm 1052^{a}$ & $26.5 \pm 1.35^{b}$ & $4.1 \pm 0.19^{b}$ & $8.0 \pm 0.35^{c}$ \\
\hline WS & $15.8 \pm 0.86^{\mathrm{a}}$ & $27.3 \pm 0.71^{b}$ & $14.1 \pm 1.02^{\mathrm{a}}$ & $27.0 \pm 1.49^{b}$ & $4.1 \pm 0.15^{b}$ & $7.9 \pm 0.49^{c}$ \\
\hline $0.25 \%$ Fe-Glu & $16.9 \pm 0.77^{a}$ & $33.1 \pm 1.14^{a}$ & $16.0 \pm 1.13^{a}$ & $32.0 \pm 1.52^{a}$ & $5.1 \pm 0.13^{a}$ & $9.8 \pm 0.29 \mathrm{ab}$ \\
\hline $0.50 \%$ Fe-Glu & $18.1 \pm 0.37^{a}$ & $33.2 \pm 0.46^{\mathrm{a}}$ & $16.5 \pm 1.15^{\mathrm{a}}$ & $31.0 \pm 1.25^{\mathrm{a}}$ & $5.8 \pm 0.15^{\mathrm{a}}$ & $10.1 \pm 0.25^{a}$ \\
\hline $0.25 \% \mathrm{FeSO}_{4}$ & $16.2 \pm 0.40^{\mathrm{a}}$ & $26.5 \pm 0.71^{b}$ & $14.0 \pm 2.00^{\mathrm{a}}$ & $29.0 \pm 1.65^{\mathrm{ab}}$ & $4.0 \pm 0.25^{b}$ & $8.0 \pm 0.35^{c}$ \\
\hline $0.5 \% \mathrm{FeSO}_{4}$ & $17.4 \pm 0.50^{\mathrm{a}}$ & $27.7 \pm 0.48^{b}$ & $14.0 \pm 1.19^{\mathrm{a}}$ & $27.0 \pm 0.98^{b}$ & $4.1 \pm 0.19^{b}$ & $9.0 \pm 0.28^{b}$ \\
\hline LSD at $5 \%$ level & \multicolumn{2}{|c|}{5.0} & \multicolumn{2}{|c|}{2.6} & \multicolumn{2}{|c|}{0.9} \\
\hline
\end{tabular}

Means with the same alphabetical letters in superscript in a column are not significantly different. Asp = aspartate; Lys = lysine; Meth = methionine; Glu = glutamate; Pro = proline; $\mathrm{GB}=$ glycine betaine. 
Table 4. N, P, K, Ca, Mg and Fe contents in root and shoot of water-stressed and non-stressed ajwain (Trachyspermum ammi L.) plants exogenously applied with different levels of Fe-Glu and $\mathrm{FeSO}_{4}$ as foliar spray at vegetative stage (mean $\pm \mathrm{SE} ; n=3$ ).

\begin{tabular}{|c|c|c|c|c|c|c|c|c|}
\hline \multirow{2}{*}{ Treatment } & \multicolumn{2}{|c|}{ N S (mg g ${ }^{-1}$ DW) } & \multicolumn{2}{|c|}{ N R (mg g ${ }^{-1}$ DW) } & \multicolumn{2}{|c|}{ P S (mg g ${ }^{-1}$ DW) } & \multicolumn{2}{|c|}{ P R (mg g $\left.{ }^{-1} \mathrm{DW}\right)$} \\
\hline & Non-Stressed & Water-Stressed & Non-Stressed & Water-Stressed & Non-Stressed & Water-Stressed & Non-Stressed & Water-Stressed \\
\hline NS & $39.01 \pm 0.50^{b}$ & $28.00 \pm 0.76^{\mathrm{b}}$ & $33.01 \pm 0.50^{\mathrm{b}}$ & $22.02 \pm 0.76^{\mathrm{b}}$ & $5.91 \pm 0.26^{\mathrm{b}}$ & $3.72 \pm 0.33^{b}$ & $4.41 \pm 0.26^{\mathrm{b}}$ & $2.22 \pm 0.33^{\mathrm{a}}$ \\
\hline WS & $39.33 \pm 0.67^{a}$ & $28.50 \pm 1.80^{b}$ & $33.33 \pm 0.67^{b}$ & $22.50 \pm 1.80^{\mathrm{b}}$ & $6.07 \pm 0.08^{\mathrm{b}}$ & $3.90 \pm 0.12^{b}$ & $4.57 \pm 0.0^{\mathrm{b}}$ & $2.40 \pm 0.12^{\mathrm{a}}$ \\
\hline $0.25 \%$ Fe-Glu & $44.17 \pm 1.17^{\mathrm{a}}$ & $32.43 \pm 0.83^{a}$ & $38.17 \pm 1.17^{a}$ & $26.43 \pm 0.83^{a}$ & $7.10 \pm 0.47^{a b}$ & $5.18 \pm 0.31^{a}$ & $5.60 \pm 0.47^{a}$ & $3.68 \pm 0.31^{b}$ \\
\hline $0.50 \%$ Fe-Glu & $44.33 \pm 1.45^{\mathrm{a}}$ & $32.50 \pm 1.04^{\mathrm{a}}$ & $38.33 \pm 1.45^{\mathrm{a}}$ & $26.50 \pm 1.04^{\mathrm{a}}$ & $7.47 \pm 0.32^{\mathrm{a}}$ & $5.10 \pm 0.40^{a b}$ & $5.97 \pm 0.32^{\mathrm{a}}$ & $3.60 \pm 0.40^{\mathrm{b}}$ \\
\hline $0.25 \% \mathrm{FeSO}_{4}$ & $39.73 \pm 2.15^{b}$ & $33.00 \pm 1.53^{\mathrm{ab}}$ & $33.73 \pm 2.15^{b}$ & $27.00 \pm 1.53^{\mathrm{a}}$ & $6.51 \pm 0.06^{\mathrm{b}}$ & $3.11 \pm 1.00^{c}$ & $5.01 \pm 0.06^{\mathrm{b}}$ & $2.61 \pm 1.00^{\mathrm{b}}$ \\
\hline $0.5 \% \mathrm{FeSO}_{4}$ & $43.83 \pm 1.30^{b}$ & $34.50 \pm 0.50^{\mathrm{a}}$ & $37.83 \pm 1.30^{\mathrm{a}}$ & $28.50 \pm 0.50^{a}$ & $6.75 \pm 0.15^{\mathrm{ab}}$ & $4.18 \pm 0.17^{\mathrm{b}}$ & $5.25 \pm 0.15^{\mathrm{ab}}$ & $2.68 \pm 0.17^{b}$ \\
\hline LSD at $5 \%$ level & & & & & & & & \\
\hline \multirow{2}{*}{ Treatment } & \multicolumn{2}{|c|}{$K S\left(\mathrm{mg} \mathrm{g}^{-1} \mathrm{DW}\right)$} & \multicolumn{2}{|c|}{$K R\left(\mathrm{mg} \mathrm{g}^{-1} \mathrm{DW}\right)$} & \multicolumn{2}{|c|}{ Ca S (mg g $\left.{ }^{-1} \mathrm{DW}\right)$} & \multicolumn{2}{|c|}{ Ca R (mg g $\left.{ }^{-1} \mathrm{DW}\right)$} \\
\hline & Non-stressed & Water-stressed & Non-stressed & Water-stressed & Non-stressed & Water-stressed & Non-stressed & Water-stressed \\
\hline NS & $32.67 \pm 1.76^{b}$ & $21.00 \pm 0.76^{\mathrm{ab}}$ & $26.01 \pm 0.50^{b}$ & $15.50 \pm 0.76^{b}$ & $3.13 \pm 0.16^{c}$ & $2.30 \pm 0.07^{b}$ & $2.10 \pm 0.03^{b}$ & $1.54 \pm 0.10^{b}$ \\
\hline WS & $32.33 \pm 0.67^{b}$ & $21.50 \pm 1.80^{b}$ & $26.33 \pm 0.67^{b}$ & $15.50 \pm 1.80^{b}$ & $3.44 \pm 0.20^{b}$ & $2.31 \pm 0.04^{b}$ & $2.23 \pm 0.03^{b}$ & $1.54 \pm 0.07^{b}$ \\
\hline $0.25 \%$ Fe-Glu & $37.17 \pm 1.17^{\mathrm{a}}$ & $25.43 \pm 0.83^{a}$ & $31.17 \pm 1.17^{\mathrm{a}}$ & $19.43 \pm 0.83^{a}$ & $4.17 \pm 0.08^{a}$ & $2.91 \pm 0.15^{\mathrm{a}}$ & $2.76 \pm 0.07^{\mathrm{a}}$ & $1.91 \pm 0.08^{a}$ \\
\hline $0.50 \%$ Fe-Glu & $37.33 \pm 1.45^{\mathrm{a}}$ & $25.50 \pm 1.04^{\mathrm{a}}$ & $31.33 \pm 1.45^{\mathrm{a}}$ & $19.50 \pm 1.04^{\mathrm{ab}}$ & $4.13 \pm 0.13^{a}$ & $3.07 \pm 0.06^{\mathrm{a}}$ & $2.82 \pm 0.09^{a}$ & $1.98 \pm 0.03^{\mathrm{a}}$ \\
\hline $0.25 \% \mathrm{FeSO}_{4}$ & $32.73 \pm 2.15^{b}$ & $26.00 \pm 1.53^{\mathrm{a}}$ & $26.73 \pm 2.15^{b}$ & $20.00 \pm 1.53^{\mathrm{a}}$ & $3.58 \pm 0.13^{b}$ & $2.39 \pm 0.03^{b}$ & $2.26 \pm 0.07^{b}$ & $1.57 \pm 0.03^{b}$ \\
\hline $0.5 \% \mathrm{FeSO}_{4}$ & $36.83 \pm 1.30^{a b}$ & $27.50 \pm 0.50^{\mathrm{a}}$ & $30.83 \pm 1.30^{a}$ & $21.50 \pm 0.50^{\mathrm{a}}$ & $3.50 \pm 0.09^{b}$ & $2.44 \pm 0.06^{b}$ & $2.37 \pm 0.01^{b}$ & $1.56 \pm 0.03^{b}$ \\
\hline LSD at $5 \%$ level & & & & & & & & \\
\hline \multirow{2}{*}{ Treatment } & \multicolumn{2}{|c|}{$\left.\operatorname{Mg~S~(mg~g~}{ }^{-1} \mathrm{DW}\right)$} & \multicolumn{2}{|c|}{$\operatorname{Mg~R}\left(\mathrm{mg} \mathrm{g}^{-1} \mathrm{DW}\right)$} & \multicolumn{2}{|c|}{ Fe S (mg g $\left.{ }^{-1} \mathrm{DW}\right)$} & \multicolumn{2}{|c|}{ Fe R $\left(\mathrm{mg} \mathrm{g}^{-1} \mathrm{DW}\right)$} \\
\hline & Non-stressed & Water-stressed & Non-stressed & Water-stressed & Non-stressed & Water-stressed & Non-stressed & Water-stressed \\
\hline NS & $2.67 \pm 0.17^{c}$ & $1.51 \pm 0.09^{b}$ & $2.17 \pm 0.17^{c}$ & $1.03 \pm 0.09^{b}$ & $22.00 \pm 0.85^{\mathrm{d}}$ & $15.00 \pm 0.35^{\mathrm{d}}$ & $20.25 \pm 0.38^{d}$ & $14.50 \pm 0.25^{\mathrm{c}}$ \\
\hline WS & $2.67 \pm 0.33^{c}$ & $1.52 \pm 0.07^{b}$ & $2.17 \pm 0.33^{c}$ & $1.02 \pm 0.07^{b}$ & $23.00 \pm 0.63^{d}$ & $16.00 \pm 0.27^{\mathrm{d}}$ & $21.25 \pm 0.53^{d}$ & $15.50 \pm 0.28^{c}$ \\
\hline $0.25 \%$ Fe-Glu & $3.17 \pm 0.17^{\mathrm{a}}$ & $1.94 \pm 0.05^{\mathrm{a}}$ & $2.67 \pm 0.17^{b}$ & $1.44 \pm 0.05^{\mathrm{a}}$ & $37.17 \pm 0.95^{b}$ & $25.43 \pm 0.47^{b c}$ & $31.17 \pm 0.78^{a b}$ & $20.00 \pm 0.33^{\mathrm{ab}}$ \\
\hline $0.50 \%$ Fe-Glu & $3.42 \pm 0.08^{b}$ & $1.98 \pm 0.07^{a}$ & $2.92 \pm 0.08^{a}$ & $1.48 \pm 0.07^{\mathrm{a}}$ & $42.50 \pm 1.35^{\mathrm{a}}$ & $28.00 \pm 0.53^{a}$ & $33.00 \pm 0.58^{a}$ & $21.50 \pm 0.35^{\mathrm{a}}$ \\
\hline $0.25 \% \mathrm{FeSO}_{4}$ & $2.72 \pm 0.15^{c}$ & $1.60 \pm 0.03^{b}$ & $2.22 \pm 0.15^{c}$ & $1.10 \pm 0.03^{\mathrm{a}}$ & $34.00 \pm 1.01^{\mathrm{c}}$ & $23.00 \pm 0.49^{c}$ & $26.73 \pm 0.45^{c}$ & $19.43 \pm 0.58^{b}$ \\
\hline $0.5 \% \mathrm{FeSO}_{4}$ & $2.67 \pm 0.17^{\mathrm{c}}$ & $1.58 \pm 0.03^{b}$ & $2.17 \pm 0.17^{c}$ & $1.08 \pm 0.03^{\mathrm{a}}$ & $36.83 \pm 0.98^{b}$ & $25.00 \pm 0.37 b c$ & $30.83 \pm 0.35^{b}$ & $19.50 \pm 0.41^{a b}$ \\
\hline LSD at $5 \%$ level & \multicolumn{2}{|c|}{0.23} & \multicolumn{2}{|c|}{0.23} & \multicolumn{2}{|c|}{2.65} & \multicolumn{2}{|c|}{2.35} \\
\hline
\end{tabular}

Means with the same alphabetical letters in superscript in a column are not significantly different. N S = Shoot N; N R = Root N; P S = Shoot P; P R = Root P; K S = Shoot K; K R = Root K; $\mathrm{Ca} \mathrm{S}=$ Shoot $\mathrm{Ca} ; \mathrm{Ca} \mathrm{R}=$ Root $\mathrm{Ca} ; \mathrm{Mg} \mathrm{S}=$ Shoot mg; Mg R = Root Mg; Fe S = Shoot Fe; Fe R = Root Fe 

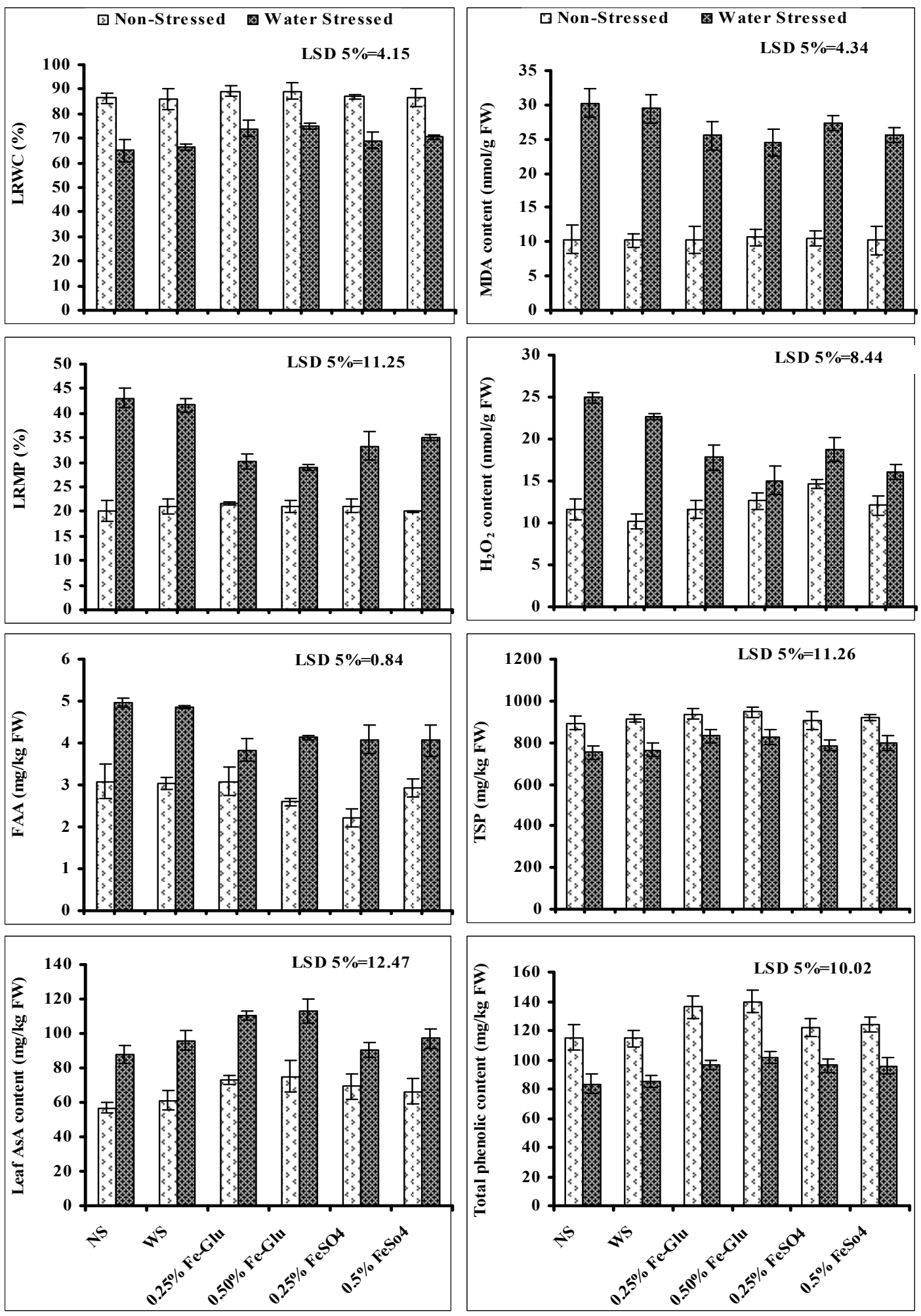

Figure 3. LRWC, MDA, LRMP, $\mathrm{H}_{2} \mathrm{O}_{2}$, FAA, TSP, AsA and total phenolic contents of water-stressed and non-stressed ajwain (Trachyspermum ammi L.) plants exogenously applied with different levels of Fe-Glu and $\mathrm{FeSO}_{4}$ as foliar spray at vegetative stage (mean $\pm \mathrm{SE} ; n=3$ ). LRWC = leaf relative water content; $\mathrm{MDA}=$ malondialdehyde; $\mathrm{LRMP}=$ leaf relative membrane permeability; FAA = free amino acids; TSP = total soluble protein; AsA = ascorbic acid. 

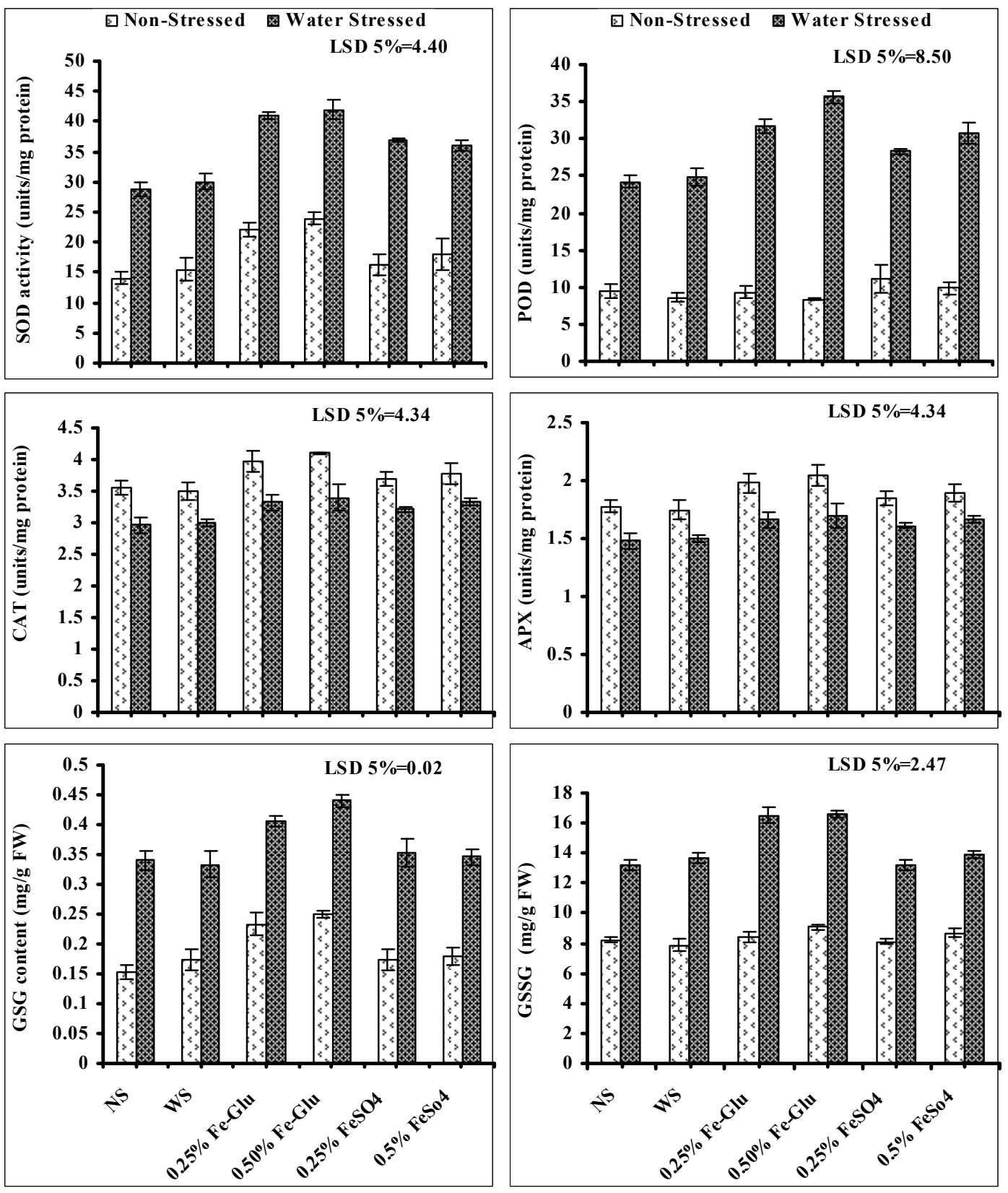

Figure 4. Activities of SOD, POD, CAT and APX and the contents of GSG and GSSG of water- stressed and non-stressed ajwain (Trachyspermum ammi L.) plants exogenously applied with different levels of Fe-Glu and $\mathrm{FeSO}_{4}$ as foliar spray at vegetative stage (mean $\pm \mathrm{SE} ; n=3$ ). SOD = superoxide dismutase; $\mathrm{POD}=$ peroxidase $\mathrm{CAT}=$ catalase $; \mathrm{APX}=$ ascorbate peroxidase $; \mathrm{GSSG}=$ oxidized glutathione; GSG $=$ reduced glutathione.

Leaf CAT and APX activities of water-stressed ajwain significantly decreased. Exogenously-applied different levels of Fe-Glu and $\mathrm{FeSO}_{4}$ were found effective in decreasing the adverse impacts of water shortage on the activities of CAT and APX. Both levels of Fe-Glu were found more effective in reducing the negative impacts of drought on APX and CAT activities in comparison with both levels of $\mathrm{FeSO}_{4}$ (Figure 4).

The correlation studies and PCA analysis for different studied attributes are being presented in Table A2 (in Appendix A) and Figure 5. The data presented in the table shows that biomass production and yield has strong positive correlation with different antioxidative compounds such as TSP $\left(0.962^{* * *}\right.$ and $\left.0.968^{* * *}\right)$, AsA $\left(0.932^{* * *}\right.$ and $\left.0.931^{* * *}\right)$, CAT $\left(0.932^{* * *}\right.$ and $\left.0.931^{* * *}\right)$, APX $\left(0.932^{* * *}\right.$ and $\left.0.931^{* * *}\right)$ and 
nutrient uptake, while a negative correlation was with LRMP $\left(-0.945^{* * *}\right.$ and $\left.-0.923^{* * *}\right)$ and MDA $\left(-0.959^{* * *}\right.$ and $\left.-0.963^{* * *}\right)$ content. The PCA analysis shows that the studied attributes have been categorized into two major components, F1 and F2, that have major contribution in defining the variance among different studied attributes. Both components (F1 and F2) have a total contribution of $92.97 \%$. The component F1 showed $78.44 \%$ contribution while the component F2 has $14.52 \%$ contribution in defining the variance among the attributes. The component F1 categorized the studied attributes in three major groups encircled on both sides of $\mathrm{F} 1$ axis. The parameters given encircled are closely positively correlated to each other (Figure 5).

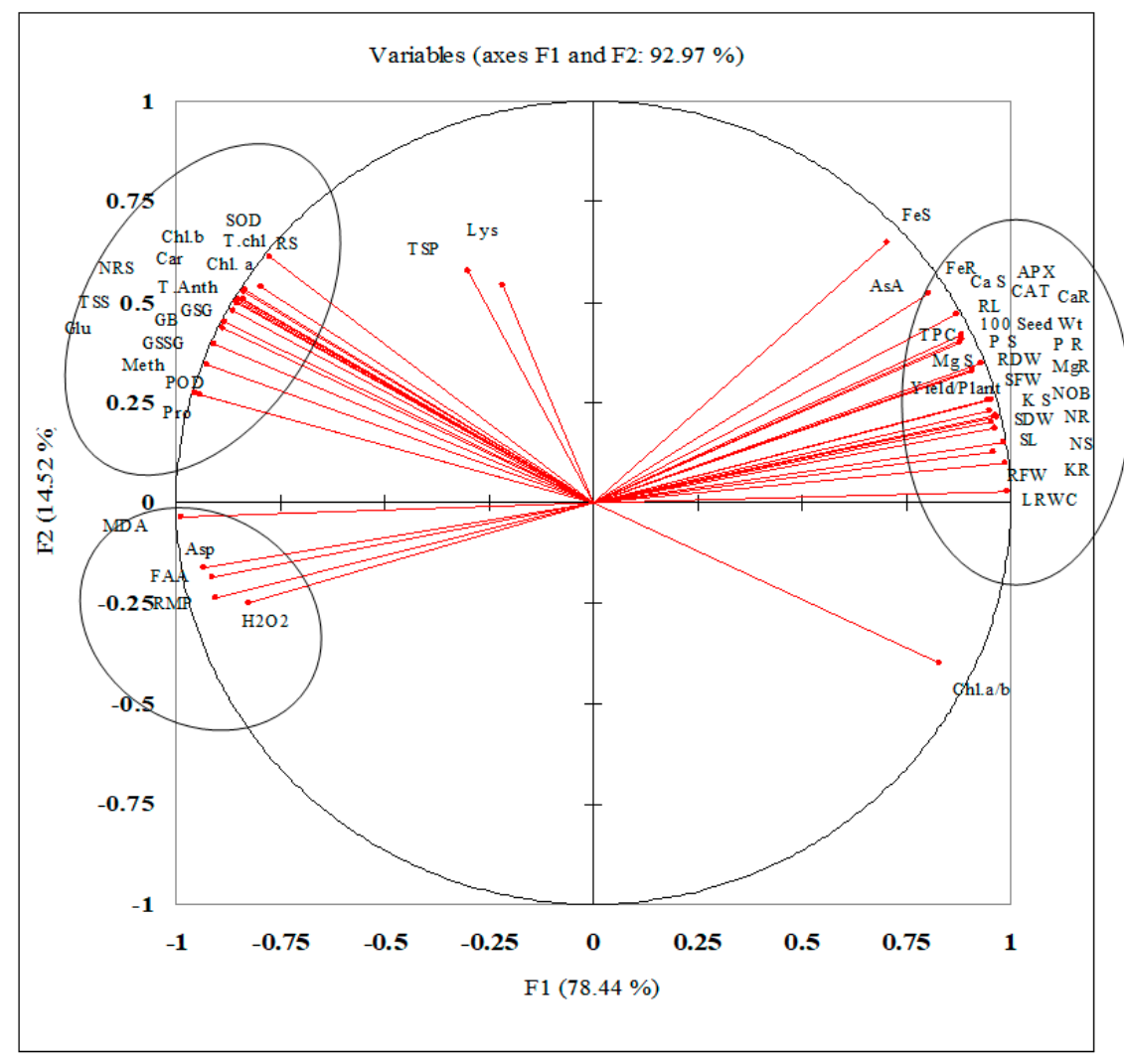

Figure 5. PCA analysis showing correlations among studied parameters of water-stressed ajwain (Trachyspermum ammi L.) plants fertigated with Fe-Glu and $\mathrm{FeSO}_{4}$ at vegetative stage. $\mathrm{SL}=$ shoot length; RL = root length; SFW = shoot fresh weight; RFW = root fresh weight; RDW = root dry weight; SDW = shoot dry weight; $\mathrm{NOB}=$ number of branches; LRWC = leaf relative water content; $\mathrm{RMP}=$ relative membrane permeability; Chl. $a=$ chlorophyll $a$; Chl. $b=$ chlorophyll $b$; Chl.a/b; T. Chl. = total chlorophyll; Car. = carotenoids; TPC = total phenolic content; $\mathrm{T}$. antho = total anthocyanin; RS = reducing sugars; TSS = total soluble sugars; FAA = free amino acids; AsA = ascorbic acid; $\mathrm{H}_{2} \mathrm{O}_{2}=$ hydrogen peroxide; $\mathrm{MDA}=$ malondialdehyde; $\mathrm{TSP}=$ total soluble proteins; $\mathrm{SOD}=$ superoxide dismutase $\mathrm{CAT}=$ catalase; $\mathrm{POD}=$ peroxidase $\mathrm{APX}=$ ascorbate peroxidase; $\mathrm{Asp}=$ aspartate; $\mathrm{Lys}=$ lysine; Meth = methionine; Glu = glutamate; Pro = proline; GB = glycine betaine; $\mathrm{N} \mathrm{S}=$ shoot nitrogen; $\mathrm{N}$ $\mathrm{R}=\operatorname{root}$ nitrogen; $\mathrm{P} \mathrm{S}=$ shoot phosphorous; $\mathrm{P} \mathrm{R}=\operatorname{root}$ phosphorous; $\mathrm{K} \mathrm{S}=\operatorname{shoot} \mathrm{K} ; \mathrm{K} \mathrm{R}=\operatorname{root} \mathrm{K}$; $\mathrm{CaS}=\operatorname{shoot} \mathrm{Ca} ; \mathrm{Ca} \mathrm{R}=\operatorname{root} \mathrm{Ca} ; \mathrm{Mg} \mathrm{S}=\operatorname{shoot} \mathrm{Mg} ; \mathrm{Mg} \mathrm{R}=\operatorname{root} \mathrm{Mg} ; \mathrm{Fe} \mathrm{S}=\operatorname{shoot} \mathrm{Fe} ; \mathrm{Fe} \mathrm{R}=\operatorname{root} \mathrm{Fe}$; GSSG = oxidized glutathione; GSG = reduced glutathione.

\section{Discussion}

For the induction of plant performance and drought tolerance, various strategies are being used for enhancing seed yield. Exogenous application of different chemicals (organic/inorganic) is found to be an effective technique being employed, including their exogenous applications through foliar spray [17]. Studies depict that application of these chemicals as foliar sprays is being absorbed and 
take part in different cellular metabolic activities through their translocation to different plant parts, in order to induce stress tolerance [61] and up-regulate their own metabolism [7,61,62]. However, in the case of using chemical fertilizers as foliar sprays, the mobility and availability after their application is a problem [20]. So, the use of these chelated compounds with improved uptake and mobilization lead to better utilization of applied compounds [24,63]. In chelation, both parts of the compound play key roles in a better way as compared with their individual application because the oxidation chances of metals increase $[21,24,28]$.

In the present study, an increase in glutamate and Fe contents was recorded both in root and shoot, when applied individually in chelated form. Furthermore, the mobility of $\mathrm{Fe}^{2+}$ was higher in case of Fe-Glu application as a foliar spray, as compared with $\mathrm{FeSO}_{4}$. This is because Fe-Glu supplied ajwain plants with more content of Fe which was found in root and shoot. This also confirms its lower oxidation when sprayed as Fe-Glu. Additionally, the increment in Fe was higher in the case of Fe-chelated glutamate as compared with $\mathrm{FeSO}_{4}$, showing a better way to overcome plant Fe deficiency. Moreover, this increased accumulation of $\mathrm{Fe}^{2+}$ and glutamate in root and shoot further describes their long-term translocation after its foliar application. In earlier studies, it has been reported that micronutrient-chelated amino acids after their absorption are taken as an amino acid, translocated to sink tissues in phloem tissue $[64,65]$. It has also been found that chelated amino acids in particular can increase the uptake and translocation of chelated metals [24,66], whereas metals in chemical form have normally low mobility and translocation within the plant [27].

In the present study, an improvement in yield and biomass product of ajwain plants is recorded with the application of both $\mathrm{Fe}^{2+}$ sources and is being found more in plants fertigated with Fe-Glu in comparison to $\mathrm{FeSO}_{4}$. This improvement in water stress tolerance in terms of yield and growth might be due to the better uptake of Fe and the availability of glutamate. It is well known that the best yield is depending on the higher biomass production as found in the present study, where the increased yield improvement was found in ajwain plants fertigated with $\mathrm{Fe}-\mathrm{Glu}$ rather than $\mathrm{FeSO}_{4}$. It might be the fact that glutamate might also have played an additional role in improving the water stress tolerance of ajwain plants [35]. It has been found earlier that foliar-supplied glutamate was found helpful in enhancing plant performance and alleviating the harmful effects of stress in faba bean and Brassica napus plants [33,35], respectively. In rice, Jie et al. [67] reported that amino acidchelated $\mathrm{Zn}$ and Fe better improved the yield as compared with respective chemical fertilizers. In a field experiment conducted on onion, it was found that onion plants supplied with $\mathrm{Zn}$-chelated amino acids performed better in terms of biomass production and yield as compared with $\mathrm{ZnSO}_{4}$ [68].

Normally, a better growth and seed yield is associated with a balanced plant water status, a significant and foremost effect that a plant faces under multiple abiotic stresses [69,70]. Similarly, in the present study, under applied water stress, a reduction in LRWC was found in ajwain plants. An improvement in LRWC due to foliar-applied $\mathrm{FeSO}_{4}$ and Fe-Glu was recorded but comparatively was found better in ajwain plants supplied with Fe-Glu. This more improvement in LRWC due to Fe-Glu foliar application might be the role of glutamate in cellular water relations [71] or its role in osmotic adjustment itself, or through its involvement in biosynthesis and accumulation of other amino acids that are important in improving the plant water relations through osmotic adjustment [31]. It is well known that glutamate is involved indirectly in the proline biosynthesis under stressful conditions [31,71]. In the present study, Fe-Glu significantly improved the plant water relations, i.e., with increased accumulation of amino acids including proline and GB that might improve the plant cellular water status along with nutrient uptake [21,61]. Furthermore, this improvement in LRWC of ajwain plants is positively related with the improved growth and seed yield.

The better growth and seed yield are also associated with the better photosynthetic activity that is directly linked with better water relations and efficient photosynthetic pigments [72,73]. An increase in leaf Chl. $a, b$ and total Chl. was recorded in ajwain plants, representing the defensive response of plants under stressful environment [74,75]. Rahbarian et al. [73] reported that increase or decrease in leaf chlorophyll and carotenoid contents under water deficit conditions is genotype- specific. In the 
present investigation, foliar-applied $\mathrm{FeSO}_{4}$ and Fe-Glu improved the biosynthesis of light-capturing compounds including Chl. $a, b$, total $\mathrm{Chl}$. as well as Car. More significant improvement in this regard was found in plants sprayed with Fe-Glu as compared with $\mathrm{FeSO}_{4}$. The similar findings have been reported in earlier studies, where an increase in photosynthetic rate $(44 \%)$ of peanut plant was recorded along with increased biosynthesis of chlorophyll pigments, upon fertigation with Fe [76]. Similarly, foliar application of Fe also improved the biosynthesis of Chl. $a, b$ and total Chl. in groundnut [77]. Furthermore, it is known that glutamate especially have a role in chlorophyll biosynthesis [78] because it was reported that plant glutamate improved the leaf $\mathrm{Chl}$. biosynthesis through lush green appearance of leaves [32]. Similar pattern might be found in the present findings where foliar-applied Fe-Glu improved the biosynthesis of Chl. $a, b$, total Chl. as well as of Car. that might have helped in better leaf photosynthetic activity by increasing the light- capturing efficiency $[72,73,76]$ along with a better stomatal regulation by the maintenance of plant cellular water content through osmotic adjustment [73], leading to better biomass production and seed yield. However, the studies reveal that the improvement in leaf photosynthetic pigments is not necessarily an indication of better photosynthetic efficiency because it also depends on the type of species and available light intensity [72]. Photosynthetic rate has been associated with a number of different factors in different crops, including stomatal and mesophyll resistance, RuDP carboxylase activity, and mesophyll cell size [79], as well as chlorophyll content [80,81] and chloroplast numbers [82]. The improvement in the biosynthesis of photosynthetic pigments in plants sprayed with Fe-Glu might be due to better Fe availability [21,76], less oxidation, as well as the additional availability of the glutamate that resulted in increased capacity to absorb sunlight.

In the present study, better growth and seed yield of water-stressed ajwain is also associated with better antioxidative defense mechanisms. Normally, lipid peroxidation is a common phenomenon in plants and its severity increases under stressful environments due to the over- production of reactive oxygen species [83]. To counteract the adversities of over-produced ROS, plants have a well-organized ROS revenging mechanism to reduce the membrane lipid peroxidation and oxidative damages to the other macromolecules [84-87]. The extent of oxidative damages due to ROS is being estimated by measuring the production of MDA or ROS. In the present study, under water stress, membrane lipid peroxidation was increased as measured in term MDA accumulation but decreased accumulation of MDA was found in plants sprayed with $\mathrm{FeSO}_{4}$ and Fe-Glu. The more decrease was recorded in Fe-Glu-sprayed ajwain plants. This decrease in lipid peroxidation in the present study is associated with increased activities of antioxidative enzymes including CAT, POD, SOD, APX as well as the increased accumulation of AsA, TPC, phenolics, GSG and GSSG as well- known non-enzymatic antioxidant in water-stressed ajwain plants sprayed with $\mathrm{FeSO}_{4}$ and Fe-Glu with a reduced accumulation of MDA, showing the role of these compounds in improving the antioxidative defense mechanism with reduced lipid per oxidation leading to improved biomass and seed yield. The more increase in antioxidative defense mechanism was in water-stressed ajwain plants foliar-supplied with Fe-Glu as compared with $\mathrm{FeSO}_{4}$, showing a better potential of Fe-Glu in improving the antioxidative defense mechanism. It might be the fact that iron acts as a prosthetic group of many peroxidases and catalases [88]. The reduced lipid peroxidation of the plants sprayed with Fe-Glu comparative with $\mathrm{FeSO}_{4}$ shows the additional properties of glutamate as a signaling molecule [35].

Plant nutrient acquisition also plays an important role in enhancing plant performance and counteracting adverse effects of water stress via regulating cellular metabolic activities, leading to better biomass and seed yield. Due to the soil lower osmotic potential under limited water supply, the disturbance in nutrient uptake is a common phenomenon that not only disturbs the cellular osmotic potential and the process of assimilation but also the final crop yield [89]. In the present study, water stress reduced nutrient acquisition of ajwain plants in terms of its uptake from soil and root to the upper part that is cleared from the reduced content of studied nutrients in roots and shoots. Foliar-supplied Fe-Glu and $\mathrm{FeSO}_{4}$ significantly improved the nutrient uptake from soil both in shoots and roots and the more uptake was in water-stressed ajwain plants foliarly-supplied with Fe-Glu. This might be due to the improved cellular water relations due to the amino acid metabolism. This improvement in the nutrient 
uptake might be due to the better cellular osmotic adjustment that resulted in more water uptake from soil along with the micro- and macro-nutrients from the rhizosphere in water-stressed ajwain plants. Furthermore, the improvement in nutrient quantity is positively correlated with improved biomass and seed yield. The findings correlate well with the previous findings where foliarly-applied glutamate at $200 \mathrm{ppm}$ increased the nutrient uptake including $\mathrm{P}, \mathrm{N}$ and $\mathrm{K}$ in leaves, stem and roots of Codiaeum variegatum L. plants that ultimately improved plant growth and yield [90]. In another study conducted by Ramezani et al. [91], it was reported that foliarly-applied $\mathrm{Fe}$ as $\mathrm{FeSO}_{4}$ considerably improved the uptake of $\mathrm{Zn}, \mathrm{Fe}$ and Se in water-stressed alfalfa plants. Moreover, in the present study, foliarly-applied $\mathrm{Fe}-\mathrm{Glu}$ and $\mathrm{FeSO}_{4}$ were also found helpful in enhancing plant growth and yield under water stress and normal irrigation conditions.

\section{Conclusions}

Foliar application of different levels of Fe-Glu was found more effective in improving the performance and the water stress tolerance of ajwain plants in terms of improved growth and yield in comparison with $\mathrm{FeSO}_{4}$. The better plant performance due to foliarly-applied Fe-Glu was due to its effective involvement in plant water relations through amino acid metabolism, increased biosynthesis of photosynthetic pigments, and efficient improvement in antioxidative defense mechanism as well as due to the improvement in nutrient acquisition. However, further field trials are needed at different locations to find out how much the exogenous use of Fe-Glu will be helpful to obtain better yield. Though the present study revealed that $0.5 \%$ level of Fe-Glu could be used as foliar spray at vegetative stage for better seed yield of ajwain, further experimentation is needed on other crops at different areas to recommend its commercial application.

Supplementary Materials: The following are available online at http://www.mdpi.com/2071-1050/12/17/7119/s1, Table S1: Field experiment layout.

Author Contributions: Conceptualization, Q.A., S.A., M.A.E.-E., M.R., M.N.A., H.A.E.-S. and F.A.A.-M.; data curation, Q.A., S.S., A.I.H., M.A.E.-E. and R.P.; formal analysis, Q.A., S.S., M.A.E.-E., R.P. and N.I.; funding acquisition, S.S., M.N.A., H.A.E.-S. and F.A.A.-M.; investigation, Q.A. and R.P.; methodology, Q.A., S.S., A.I.H., M.A.E.-E., R.P. and N.I.; project administration, N.I.; resources, S.A., M.R., M.N.A., M.A.E.-E., H.A.E.-S. and F.A.A.-M.; software, M.A.E.-E., M.R. and F.A.A.-M.; supervision, Q.A. and N.I.; validation, M.A.E.-E., A.I.H.; visualization, A.I.H.; writing-original draft, Q.A., S.A., M.A.E.-E. and M.R.; writing-review and editing, S.A., M.A.E.-E., M.N.A., H.A.E.-S. and F.A.A.-M. All authors have read and agreed to the published version of the manuscript.

Funding: The authors would like to extend their sincere appreciation to the Researchers Supporting Project Number (RSP-2020/19), King Saud University, Riyadh, Saudi Arabia. The authors are also grateful to Higher Education Commission (HEC) Islamabad, Pakistan, for its support.

Acknowledgments: The authors would like to extend their sincere appreciation to the Researchers Supporting Project Number (RSP-2020/19), King Saud University, Riyadh, Saudi Arabia. The authors are also grateful to Government College University Faisalabad, Pakistan for its support.

Conflicts of Interest: The authors declare that there is no conflict of interests regarding the publication of this paper.

\section{Abbreviations}

$\begin{array}{ll}\text { SL } & \text { shoot length } \\ \text { RL } & \text { root length } \\ \text { SFW } & \text { shoot fresh weight } \\ \text { RFW } & \text { root fresh weight } \\ \text { RDW } & \text { root dry weight } \\ \text { SDW } & \text { shoot dry weight } \\ \text { NOB } & \text { number of branches } \\ \text { LRWC } & \text { leaf relative water content } \\ \text { RMP } & \text { relative membrane permeability } \\ \text { Chl. } a & \text { chlorophyll } a \\ \text { Chl. } b & \text { chlorophyll } b \\ \text { Chl. } a / b & \text { chlorophyll } a / b \text { ratio }\end{array}$




$\begin{array}{ll}\text { T. Chl. } & \text { total chlorophyll } \\ \text { Car. } & \text { carotenoids } \\ \text { TPC } & \text { total phenolic content } \\ \text { T. antho } & \text { total anthocyanin } \\ \text { RS } & \text { reducing sugars } \\ \text { TSS } & \text { total soluble sugars } \\ \text { FAA } & \text { free amino acids } \\ \text { AsA } & \text { ascorbic acid } \\ \mathrm{H}_{2} \mathrm{O}_{2} & \text { hydrogen peroxide } \\ \mathrm{MDA} & \text { malondialdehyde } \\ \text { TSP } & \text { total soluble proteins } \\ \text { SOD } & \text { superoxide dismutase } \\ \text { CAT } & \text { catalase } \\ \text { POD } & \text { peroxidase } \\ \text { APX } & \text { ascorbate peroxidase } \\ \text { Asp } & \text { aspartate } \\ \text { Lys } & \text { lysine } \\ \text { Meth } & \text { methionine } \\ \text { Glu } & \text { glutamate } \\ \text { Pro } & \text { proline } \\ \text { GB } & \text { glycine betaine } \\ \text { N S } & \text { shoot nitrogen } \\ \text { N R } & \text { root nitrogen } \\ \text { P S } & \text { shoot phosphorous } \\ \text { P R } & \text { root phosphorous } \\ \text { K S } & \text { shoot K } \\ \text { K R } & \text { root K } \\ \text { Ca S } & \text { shoot Ca } \\ \text { Ca R } & \text { root Ca } \\ \text { Mg S } & \text { shoot Mg } \\ \text { Mg R } & \text { root Mg } \\ \text { Fe S } & \text { shoot Fe } \\ \text { Fe R } & \text { root Fe } \\ \text { GSSG } & \text { ridized glutathione } \\ \text { GSG } & \end{array}$




\section{Appendix A}

Table A1. Spearman's correlation coefficient $\left(r^{2}\right)$ values of the studied attributes of ajwain plants exogenously supplied with different levels of FeSO ${ }_{4}$ and Fe-Glu as foliar spray when grown under water-stressed and non-stressed conditions.

\begin{tabular}{|c|c|c|c|c|c|c|c|c|c|}
\hline Variables & SL & RL & RFW & SFW & RDW & SDW & NOU & Seed Yield/Plant & 100 Seed Weight \\
\hline SL & 1 & $0.946^{* * *}$ & $0.992 * * *$ & $0.966^{* * *}$ & $0.981 * * *$ & $0.985^{* * *}$ & $0.978^{* * *}$ & $0.990^{* * *}$ & $0.955^{* * *}$ \\
\hline RL & $0.946^{* * *}$ & 1 & $0.932^{* * *}$ & $0.959^{* * *}$ & $0.938^{* * *}$ & $0.975^{* * *}$ & $0.960^{* * *}$ & $0.952^{* * *}$ & $0.959^{* * *}$ \\
\hline RFW & $0.992 * * *$ & $0.932^{* * *}$ & 1 & $0.974 * * *$ & $0.976^{* * *}$ & $0.984^{* * *}$ & $0.985^{* * *}$ & $0.985^{* * *}$ & $0.950 * * *$ \\
\hline SFW & $0.966^{* * *}$ & $0.959 * * *$ & $0.974^{* * *}$ & 1 & $0.964^{* * *}$ & $0.975^{* * *}$ & $0.986^{* * *}$ & $0.959 * * *$ & $0.941^{* * *}$ \\
\hline RDW & $0.981^{* * *}$ & $0.938^{* * *}$ & $0.976^{* * *}$ & $0.964^{* * *}$ & 1 & $0.980 * * *$ & $0.969 * * *$ & $0.987^{* * *}$ & $0.942 * * *$ \\
\hline SDW & $0.985^{* * *}$ & $0.975^{* * *}$ & $0.984^{* * *}$ & $0.975^{* * *}$ & $0.980 * * *$ & 1 & $0.984^{* * *}$ & $0.993^{* * *}$ & $0.978^{* * *}$ \\
\hline NOB & $0.978^{* * *}$ & $0.960 * * *$ & $0.985^{* * *}$ & $0.986^{* * *}$ & $0.969 * * *$ & $0.984^{* * *}$ & 1 & $0.969 * * *$ & $0.939 * * *$ \\
\hline LRWC & $0.975^{* * *}$ & $0.869^{* * *}$ & $0.971^{* * *}$ & $0.935^{* * *}$ & $0.968^{* * *}$ & $0.938^{* * *}$ & $0.944^{* * *}$ & $0.955^{* * *}$ & $0.893^{* * *}$ \\
\hline RMP & $-0.942^{* * *}$ & $-0.950 * * *$ & $-0.942 * * *$ & $-0.949 * * *$ & $-0.891^{* * *}$ & $-0.945^{* * *}$ & $-0.950^{* * *}$ & $-0.923^{* * *}$ & $-0.936^{* * *}$ \\
\hline Chl. a & $-0.737^{* * *}$ & $-0.519^{* *}$ & $-0.767^{* * *}$ & $-0.682 * * *$ & $-0.687^{* * *}$ & $-0.647^{* * *}$ & $-0.709^{* * *}$ & $-0.672^{* * *}$ & $-0.560^{* * *}$ \\
\hline Chl. b & $-0.753^{* * *}$ & $-0.531^{* *}$ & $-0.788^{* * *}$ & $-0.701^{* * *}$ & $-0.717^{* * *}$ & $-0.671^{* * *}$ & $-0.727^{* * *}$ & $-0.698^{* * *}$ & $-0.587^{* * *}$ \\
\hline Chl. a/b & $0.740 * * *$ & $0.542 * *$ & $0.790^{* * *}$ & $0.701^{* * *}$ & $0.715^{* * *}$ & $0.688^{* * *}$ & $0.736^{* * *}$ & $0.713^{* * *}$ & $0.631^{* * *}$ \\
\hline T. Chl. & $-0.742^{* * *}$ & $-0.523^{* *}$ & $-0.773^{* * *}$ & $-0.687^{* * *}$ & $-0.695^{* * *}$ & $-0.654^{* * *}$ & $-0.714^{* * *}$ & $-0.678^{* * *}$ & $-0.566^{* * *}$ \\
\hline Car. & $-0.762^{* * *}$ & $-0.536^{* *}$ & $-0.792^{* * *}$ & $-0.692^{* * *}$ & $-0.724^{* * *}$ & $-0.686^{* * *}$ & $-0.720^{* * *}$ & $-0.721^{* * *}$ & $-0.623^{* * *}$ \\
\hline TPC & $0.964^{* * *}$ & $0.951^{* * *}$ & $0.938^{* * *}$ & $0.943^{* * *}$ & $0.977^{* * *}$ & $0.962^{* * *}$ & $0.936^{* * *}$ & $0.968^{* * *}$ & $0.938^{* * *}$ \\
\hline T. Antho & $-0.738^{* * *}$ & $-0.505^{* *}$ & $-0.762^{* * *}$ & $-0.678^{* * *}$ & $-0.699 * * *$ & $-0.640^{* * *}$ & $-0.698^{* * *}$ & $-0.673^{* * *}$ & $-0.556^{* *}$ \\
\hline RS & $-0.665^{* * *}$ & $-0.425 *$ & $-0.703^{* * *}$ & $-0.605^{* * *}$ & $-0.632^{* * *}$ & $-0.581^{* * *}$ & $-0.632^{* * *}$ & $-0.613^{* * *}$ & $-0.491^{* *}$ \\
\hline TSS & $-0.769^{* * *}$ & $-0.545^{* *}$ & $-0.793 * * *$ & $-0.707^{* * *}$ & $-0.721^{* * *}$ & $-0.680^{* * *}$ & $-0.717^{* * *}$ & $-0.711^{* * *}$ & $-0.616^{* * *}$ \\
\hline FAA & $-0.936^{* * *}$ & $-0.937^{* * *}$ & $-0.928^{* * *}$ & $-0.943^{* * *}$ & $-0.905^{* * *}$ & $-0.926^{* * *}$ & $-0.964^{* * *}$ & $-0.899 * * *$ & $-0.865^{* * *}$ \\
\hline AsA & $0.924^{* * *}$ & $0.950^{* * *}$ & $0.892^{* * *}$ & $0.925^{* * *}$ & $0.947^{* * *}$ & $0.932 * * *$ & $0.909 * * *$ & $0.931^{* * *}$ & $0.916^{* * *}$ \\
\hline $\mathrm{H}_{2} \mathrm{O}_{2}$ & $-0.867^{* * *}$ & $-0.853^{* * *}$ & $-0.854^{* * *}$ & $-0.849^{* * *}$ & $-0.803^{* * *}$ & $-0.847^{* * *}$ & $-0.850^{* * *}$ & $-0.844^{* * *}$ & $-0.868^{* * *}$ \\
\hline MDA & $-0.986^{* * *}$ & $-0.907^{* * *}$ & $-0.990 * * *$ & $-0.959^{* * *}$ & $-0.951^{* * *}$ & $-0.959^{* * *}$ & $-0.972^{* * *}$ & $-0.963^{* * *}$ & $-0.927^{* * *}$ \\
\hline TSP & $-0.184 \mathrm{~ns}$ & $-0.031 \mathrm{~ns}$ & $-0.194 n s$ & $-0.053 \mathrm{~ns}$ & $-0.087 \mathrm{~ns}$ & $-0.138 \mathrm{~ns}$ & $-0.089 \mathrm{~ns}$ & $-0.165 n s$ & $-0.190 \mathrm{~ns}$ \\
\hline POD & $-0.879^{* * *}$ & $-0.700^{* * *}$ & $-0.897^{* * *}$ & $-0.824^{* * *}$ & $-0.876^{* * *}$ & $-0.824^{* * *}$ & $-0.838^{* * *}$ & $-0.856^{* * *}$ & $-0.761^{* * *}$ \\
\hline SOD & $-0.765^{* * *}$ & $-0.547^{* *}$ & $-0.798^{* * *}$ & $-0.707^{* * *}$ & $-0.727^{* * *}$ & $-0.690^{* * *}$ & $-0.733^{* * *}$ & $-0.719 * * *$ & $-0.617^{* * *}$ \\
\hline CAT & $0.924^{* * *}$ & $0.950 * * *$ & $0.892 * * *$ & $0.925^{* * *}$ & $0.947 * * *$ & $0.932^{* * *}$ & $0.909 * * *$ & $0.931^{* * *}$ & $0.916^{* * *}$ \\
\hline APX & $0.924^{* * *}$ & $0.950^{* * *}$ & $0.892^{* * *}$ & $0.925^{* * *}$ & $0.947^{* * *}$ & $0.932^{* * *}$ & $0.909^{* * *}$ & $0.931^{* * *}$ & $0.916^{* * *}$ \\
\hline Asp & $-0.960^{* * *}$ & $-0.936^{* * *}$ & $-0.970 * * *$ & $-0.945^{* * *}$ & $-0.925^{* * *}$ & $-0.972^{* * *}$ & $-0.960^{* * *}$ & $-0.960^{* * *}$ & $-0.972^{* * *}$ \\
\hline Lys & $-0.249 \mathrm{~ns}$ & $-0.115 \mathrm{~ns}$ & $-0.296 \mathrm{~ns}$ & $-0.166 \mathrm{~ns}$ & $-0.212 \mathrm{~ns}$ & $-0.230 \mathrm{~ns}$ & $-0.280 \mathrm{~ns}$ & $-0.242 \mathrm{~ns}$ & $-0.135 \mathrm{~ns}$ \\
\hline Meth & $-0.853^{* * *}$ & $-0.652^{* * *}$ & $-0.863^{* * *}$ & $-0.782^{* * *}$ & $-0.825^{* * *}$ & $-0.773^{* * *}$ & $-0.804^{* * *}$ & $-0.806^{* * *}$ & $-0.694^{* * *}$ \\
\hline
\end{tabular}


Table A2. Cont.

\begin{tabular}{|c|c|c|c|c|c|c|c|c|c|}
\hline Variables & SL & RL & RFW & SFW & RDW & SDW & NOU & Seed Yield/Plant & 100 Seed Weight \\
\hline Glu & $-0.853^{* * *}$ & $-0.652 * * *$ & $-0.863^{* * *}$ & $-0.782 * * *$ & $-0.825^{* * *}$ & $-0.773^{* * *}$ & $-0.804^{* * *}$ & $-0.806^{* * *}$ & $-0.694^{* * *}$ \\
\hline Pro & $-0.895^{* * *}$ & $-0.719^{* * *}$ & $-0.911^{* * *}$ & $-0.846^{* * *}$ & $-0.867^{* * *}$ & $-0.831^{* * *}$ & $-0.865^{* * *}$ & $-0.855^{* * *}$ & $-0.765^{* * *}$ \\
\hline GB & $-0.830^{* * *}$ & $-0.642 * * *$ & $-0.860 * * *$ & $-0.784^{* * *}$ & $-0.795^{* * *}$ & $-0.764^{* * *}$ & $-0.806^{* * *}$ & $-0.785 * * *$ & $-0.678^{* * *}$ \\
\hline N S & $0.950 * * *$ & $0.873^{* * *}$ & $0.942^{* * *}$ & $0.940^{* * *}$ & $0.937^{* * *}$ & $0.917^{* * *}$ & $0.911^{* * *}$ & $0.927^{* * *}$ & $0.902 * * *$ \\
\hline $\mathbf{N} \mathbf{R}$ & $0.950 * * *$ & $0.873^{* * *}$ & $0.942^{* * *}$ & $0.940 * * *$ & $0.937^{* * *}$ & $0.917^{* * *}$ & $0.911^{* * *}$ & $0.927^{* * *}$ & $0.902^{* * *}$ \\
\hline P S & $0.946^{* * *}$ & $0.950 * * *$ & $0.944^{* * *}$ & $0.947^{* * *}$ & $0.967^{* * *}$ & $0.972^{* * *}$ & $0.954^{* * *}$ & $0.969^{* * *}$ & $0.965^{* * *}$ \\
\hline $\mathbf{P} \mathbf{R}$ & $0.946^{* * *}$ & $0.950 * * *$ & $0.944^{* * *}$ & $0.947^{* * *}$ & $0.967^{* * *}$ & $0.972 * * *$ & $0.954^{* * *}$ & $0.969^{* * *}$ & $0.965^{* * *}$ \\
\hline K S & $0.951^{* * *}$ & $0.888^{* * *}$ & $0.943^{* * *}$ & $0.942 * * *$ & $0.961^{* * *}$ & $0.930 * * *$ & $0.925^{* * *}$ & $0.941^{* * *}$ & $0.902 * * *$ \\
\hline K R & $0.950 * * *$ & $0.873^{* * *}$ & $0.942^{* * *}$ & $0.940 * * *$ & $0.937^{* * *}$ & $0.917^{* * *}$ & $0.911^{* * *}$ & $0.927^{* * *}$ & $0.902^{* * *}$ \\
\hline Ca S & $0.941^{* * *}$ & $0.953^{* * *}$ & $0.920^{* * *}$ & $0.905^{* * *}$ & $0.961^{* * *}$ & $0.966^{* * *}$ & $0.921^{* * *}$ & $0.971^{* * *}$ & $0.960^{* * *}$ \\
\hline Ca $R$ & $0.930^{* * *}$ & $0.934^{* * *}$ & $0.913^{* * *}$ & $0.902^{* * *}$ & $0.962 * * *$ & $0.957^{* * *}$ & $0.904^{* * *}$ & $0.966^{* * *}$ & $0.958^{* * *}$ \\
\hline $\operatorname{Mg~S}$ & $0.975^{* * *}$ & $0.941^{* * *}$ & $0.958^{* * *}$ & $0.937^{* * *}$ & $0.982 * * *$ & $0.975^{* * *}$ & $0.941^{* * *}$ & $0.985^{* * *}$ & $0.966^{* * *}$ \\
\hline Mg R & $0.975^{* * *}$ & $0.941^{* * *}$ & $0.958^{* * *}$ & $0.937^{* * *}$ & $0.982 * * *$ & $0.975^{* * *}$ & $0.941^{* * *}$ & $0.985^{* * *}$ & $0.966^{* * *}$ \\
\hline Fe S & $0.775^{* * *}$ & $0.876^{* * *}$ & $0.742^{* * *}$ & $0.823^{* * *}$ & $0.833^{* * *}$ & $0.817^{* * *}$ & $0.800^{* * *}$ & $0.799^{* * *}$ & $0.784^{* * *}$ \\
\hline Fe R & $0.850^{* * *}$ & $0.900^{* * *}$ & $0.829^{* * *}$ & $0.883^{* * *}$ & $0.907^{* * *}$ & $0.880^{* * *}$ & $0.859^{* * *}$ & $0.875^{* * *}$ & $0.841^{* * *}$ \\
\hline $\begin{array}{c}\text { Seed } \\
\text { yield/plant }\end{array}$ & $0.990^{* * *}$ & $0.952^{* * *}$ & $0.985^{* * *}$ & $0.959 * * *$ & $0.987^{* * *}$ & $0.993^{* * *}$ & $0.969^{* * *}$ & 1 & $0.975^{* * *}$ \\
\hline $\begin{array}{c}100 \text { seed } \\
\text { weight }\end{array}$ & $0.955^{* * *}$ & $0.959^{* * *}$ & $0.950^{* * *}$ & $0.941^{* * *}$ & $0.942^{* * *}$ & $0.978^{* * *}$ & $0.939^{* * *}$ & $0.975^{* * *}$ & 1 \\
\hline GSSG & $-0.853^{* * *}$ & $-0.652^{* * *}$ & $-0.863^{* * *}$ & $-0.782 * * *$ & $-0.825^{* * *}$ & $-0.773^{* * *}$ & $-0.804^{* * *}$ & $-0.806^{* * *}$ & $-0.694^{* * *}$ \\
\hline GSG & $-0.805^{* * *}$ & $-0.607^{* * *}$ & $-0.834^{* * *}$ & $-0.764^{* * *}$ & $-0.761^{* * *}$ & $-0.727^{* * *}$ & $-0.783^{* * *}$ & $-0.746^{* * *}$ & $-0.645^{* * *}$ \\
\hline
\end{tabular}

$*, * *$ and ${ }^{* * *}=$ significant at $5 \%, 1 \%$ and $0.1 \%$ levels, respectively; ns = non-significant. 


\section{References}

1. Mancosu, N.; Snyder, R.; Kyriakakis, G.; Spano, D. Water Scarcity and Future Challenges for Food Production. Water 2015, 7, 975-992. [CrossRef]

2. El-Esawi, M.A.; Alaraidh, I.A.; Alsahli, A.A.; Alzahrani, S.M.; Ali, H.M.; Alayafi, A.A.; Ahmad, M. Serratia liquefaciens KM4 Improves Salt Stress Tolerance in Maize by Regulating Redox Potential, Ion Homeostasis, Leaf Gas Exchange and Stress-Related Gene Expression. Int. J. Mol. Sci. 2018, 19, 3310. [CrossRef] [PubMed]

3. Vwioko, E.; Adinkwu, O.; El-Esawi, M.A. Comparative Physiological, Biochemical and Genetic Responses to Prolonged Waterlogging Stress in Okra and Maize Given Exogenous Ethylene Priming. Front. Physiol. 2017, 8, 632. [CrossRef]

4. Ali, Q.; Haider, M.Z.; Iftikhar, W.; Jamil, S.; Javed, M.T.; Noman, A.; Iqbal, M.; Perveen, R. Drought Tolerance Potential of Vigna mungo L. Lines as Deciphered by Modulated Growth, Antioxidant Defense, and Nutrient Acquisition Patterns. Braz. J. Bot. 2016, 39, 801-812. [CrossRef]

5. El-Esawi, M.A.; Al-Ghamdi, A.A.; Ali, H.M.; Ahmad, M. Overexpression of AtWRKY30 Transcription Factor Enhances Heat and Drought Stress Tolerance in Wheat (Triticum aestivum L.). Genes 2019, 10, 163. [CrossRef] [PubMed]

6. El-Esawi, M.A.; Alayafi, A.A. Overexpression of rice Rab7 gene improves drought and heat tolerance and increases grain yield in rice (Oryza sativa L.). Genes 2019, 10, 56. [CrossRef]

7. Noman, A.; Ali, Q.; Naseem, J.; Javed, M.T.; Kanwal, H.; Islam, W.; Aqeel, W.; Khalid, N.; Zafar, S.; Tayyeb, M.; et al. Sugar Beet Extract Acts as a Natural Bio-Stimulant for Physio-Biochemical Attributes in Water Stressed Wheat (Triticum aestivum L.). Acta Physiol. Plant. 2018, 40, 1-17. [CrossRef]

8. El-Esawi, M.A.; Germaine, K.; Bourke, P.; Malone, R. AFLP analysis of genetic diversity and phylogenetic relationships of Brassica oleracea in Ireland. Comptes Rendus Biol. 2016, 339, 163-170. [CrossRef]

9. El-Esawi, M.A. Genetic diversity and evolution of Brassica genetic resources: From morphology to novel genomic technologies-A review. Plant Genet. Resour. 2017, 15, 388-399. [CrossRef]

10. El-Esawi, M.A.; Sammour, R. Karyological and phylogenetic studies in the genus Lactuca L. (Asteraceae). Cytologia 2014, 79, 269-275. [CrossRef]

11. Silva, E.C.; Nogueira, R.J.M.C.; da Silva, M.A.; de Albuquerque, M.B. Drought Stress and Plant Nutrition. Plant Stress 2011, 5, 32-41.

12. Rout, G.R.; Sahoo, S. Role of Iron in Plant Growth and Metabolism. Rev. Agric. Sci. 2015, 3, 1-24. [CrossRef]

13. Schmidt, W. Iron Stress-Induced Redox Reactions in Bean Roots. Physiol. Plant. 1993, 89, 448-452. [CrossRef]

14. Young, V.R.; Ajami, A.M. Glutamate: An Amino Acid of Particular Distinction. J. Nutr. 2000, 130, 892S-900S. [CrossRef]

15. Liu, J.; Chakraborty, S.; Hosseinzadeh, P.; Yu, Y.; Tian, S.; Petrik, I.; Bhagi, A.; Lu, Y. Metalloproteins Containing Cytochrome, Iron-Sulfur, or Copper Redox Centers. Chem. Rev. 2014, 114, 4366-4469. [CrossRef]

16. Bertini, I.; Rosato, A. From Genes to Metalloproteins: A Bioinformatic Approach. Eur. J. Inorg. Chem. 2007, 18, 2546-2555. [CrossRef]

17. Ghorbani, S.; Khiabani, B.N.; Amini, I.; Ardakani, M.R.; Pirdashti, H.; Moakhar, S.R. Effect of Iron and Zinc on Yield and Yield Components of Mutant Line's Wheat. Asian J. Bio. Sci. 2009, 2, 74-80.

18. Laan, P.; Smolders, A.J.P.; Blom, C.W.P.M. The Relative Importance of Anaerobiosis and High Iron Levels in Flood Tolerance of Rumex Species. Plant Soil 1991, 136, 153-161. [CrossRef]

19. Sánchez, A.S.; Juárez, M.; Sánchez-Andreu, J.; Jordá, J.; Bermúdez, D. Use of Humic Substances and Amino Acids to Enhance Iron Availability for Tomato Plants from Applications of the Chelate FeEDDHA. J. Plant Nutr. 2005, 28, 1877-1886. [CrossRef]

20. Ghasemi, S.; Khoshgoftarmanesh, A.H.; Afyuni, M.; Hadadzadeh, H. Iron (II)-amino Acid Chelates Alleviate Salt-Stress Induced Oxidative Damages on Tomato Grown in Nutrient Solution Culture. Sci. Hortic. 2014, 165, 91-98. [CrossRef]

21. Souri, M.K.; Hatamian, M. Aminochelates in Plant Nutrition: A Review. J. Plant Nutr. 2018, 1-12. [CrossRef]

22. Parmar, K.A.; Prajapati, S.; Patel, R.; Dabhi, Y. Effective Use of Ferrous Sulfate and Alum as a Coagulant in Treatment of Dairy Industry Waste Water. ARPN J. Engin. Appl. Sci. 2011, 6, 42-45.

23. Fernández, V.; Ebert, G. Foliar Iron Fertilization: A Critical Review. J. Plant Nutr. 2005, 28, $2113-2124$. [CrossRef] 
24. Souri, M.K. Aminochelate Fertilizers: The New Approach to the Old Problem; a Review. Open Agric. 2016, 1, 118-123. [CrossRef]

25. Parasad, R. Fertilizer Urea, Food Security, Health and the Environment. Curr. Sci. 1998, 75, 675-683.

26. Fageria, N.K.; Baligar, V.C. Enhancing nitrogen use efficiency in crop plants. Adv. Agron. 2005, 88, 97-185.

27. Marschner, P. Marschner's Mineral Nutrition of Higher Plants, 3rd ed.; Elsevier: London, UK, 2011.

28. Ghasemi, S.; Khoshgoftarmanesh, A.H.; Afyuni, M.; Hadadzadeh, H. The Effectiveness of Foliar Applications of Synthesized Zinc-Amino Acid Chelates in Comparison with Zinc Sulfate to Increase Yield and Grain Nutritional Quality of Wheat. Eur. J. Agron. 2013, 45, 68-74. [CrossRef]

29. Rizwan, M.; Ali, S.; Hussain, A.; Ali, Q.; Shakoor, M.B.; Zia-ur-Rehman, M.; Farid, M.; Asma, M. Effect of Zinc-Lysine on Growth, Yield and Cadmium Uptake in Wheat (Triticum aestivum L.) and Health Risk Assessment. Chemosphere 2017, 187, 35-42. [CrossRef]

30. Slocum, R.D. Genes, Enzymes and Regulation of Arginine Biosynthesis in Plants. Plant Physiol. Biochem. 2005, 43, 729-745. [CrossRef]

31. Ali, Q.; Athar, H.B.; Haider, M.Z.; Shahid, S.; Aslam, N.; Shehzad, F.; Naseem, J.; Ashraf, R.; Ali, A.; Hussain, S.M. Role of Amino Acids in Improving Abiotic Stress Tolerance to Plants. In Plant Tolerance to Environmental Stress: Role of Phytoprotectants; Hasanuzzaman, M., Fujita, M., Oku, H., Islam, M.T., Eds.; CRC Press Taylor and Francis: Oxfordshire, UK, 2019; pp. 175-203.

32. Dinu, C.A.; Moraru, D.; Paraschiv, N.L. The Physiology of Glutamic Acid. Agron. Series Sci. Res. Lucr. Stiintifice Ser. Agron. 2011, 54, 53-55.

33. Stolarz, M.; Dziubinska, H. Osmotic and Salt Stresses Modulate Spontaneous and Glutamate-Induced Action Potentials and Distinguish Between Growth and Circumnutation in Helianthus annuus Seedlings. Front. Plant Sci. 2017, 8, 1766. [CrossRef] [PubMed]

34. Ramos, M.L.G.; Parsons, R.; Sprent, J.I. Differences in Ureide and Amino Acid Content of Water Stressed Soybean Inoculated With Bradyrhizobium japonicum and B. elkanii. Pesqui. Agropecuária Bras. 2005, 40, 453-458. [CrossRef]

35. Sadak, M.S.H.; Abdelhamid, M.T.; Schmidhalter, U. Effect of Foliar Application of Amino Acids on Plant Yield and Some Physiological Parameters in Bean Plants Irrigated With Seawater. Acta Biológica Colomb. 2015, 20, 141-152.

36. Yadav, R.; Chandan, K.P.; Deepika, G.; Rahul, K. Health Benefits of Indian Aromatic Plant Ajwain (Trachycpermum ammi). Int. J. Pharm. Technol. 2011, 3, 1356-1366.

37. Singh, G.; Kapoor, I.P.; Pandey, S.K.; Singh, U.K.; Singh, R.K. Studies on Essential Oils: Part 10; Antibacterial Activity of Volatile Oils of Some Spices. Phytother. Res. 2002, 16, 680-682. [CrossRef]

38. Davis, J.; Freitas, F. Physical and Chemical Methods of Soil and Water Analysis, Soil Bulletin 10; Food and Agricultural Organizations: Rome, Italy, 1970.

39. Leu, M. Metal Lysine Complexes and Method for Producing Metal Lysine Complexes. US Patent 5,061,815, 29 October 1991.

40. Ali, Q.; Ali, S.; El-Esawi, M.A.; Rizwan, M.; Azeem, M.; Hussain, A.I.; Perveen, R.; El-Sheikh, M.A.; Alyemeni, M.N.; Wijaya, L. Foliar Spray of Fe-Asp Confers Better Drought Tolerance in Sunflower as Compared with $\mathrm{FeSO}_{4}$ : Yield Traits, Osmotic Adjustment, and Antioxidative Defense Mechanisms. Biomolecules 2020, 10, 1217. [CrossRef]

41. Yang, X.J.; Ogryzko, V.V.; Nishikawa, J.I.; Howard, B.H.; Nakatani, Y. A p300/CBP-Associated Factor That Competes With the Adenoviral on Coprotein E1A. Nature 1996, 382, 319. [CrossRef]

42. Arnon, D.I. Copper Enzymes in Isolated Chloroplasts. Polyphenoloxidase in Beta vulgaris. Plant Physiol. 1949, 24, 1. [CrossRef]

43. Kirk, J.T.O.; Allen, R.L. Dependence of Chloroplast Pigment Synthesis on Protein Synthesis: Effect of Actidione. Biochem. Biophys. Res. Commun. 1965, 21, 523-530. [CrossRef]

44. Julkenen-Titto, R. Phenolic Constituents in the Leaves of Northern Willows: Methods for the Analysis of Certain Phenolics. Agric. Food Chem. 1985, 3, 213-217. [CrossRef]

45. Mukherjee, S.P.; Choudhuri, M.A. Implications of Water Stress-Induced Changes in the Levels of Endogenous Ascorbic Acid and Hydrogen Peroxide in Vigna Seedlings. Physiol. Plant. 1983, 58, 166-170. [CrossRef]

46. Bradford, M.M. A Rapid and Sensitive Method for the Quantitation of Microgram Quantities of Protein Utilizing the Principle of Protein-Dye Binding. Analyt. Biochem. 1976, 72, 248-254. [CrossRef] 
47. Giannopolitis, C.N.; Ries, S.K. Superoxide dismutases I. Occurrence in Higher Plants. Plant Physiol. 1977, 59, 309-314. [CrossRef] [PubMed]

48. Chance, B.; Maehly, A.C. Assay of Catalases and Peroxidases. Methods Enzymol. 1955, 2, 764-775.

49. Asada, K.; Takahashi, M. Production and Scavenging of Active Oxygen in Chloroplasts. In Photoinhibition; Kyle, D.J., Osmond, C.B., Arntzen, C.J., Eds.; Elsevier: Amsterdam, The Nederland, 1987; pp. 227-287.

50. Hamilton, P.B.; Van Slyke, D.D. The Gasometric Determination of Free Amino Acids in Blood Filtrates by the Ninhydrin-Carbon Dioxide Method. J. Biol. Chem. 1943, 150, 231-250.

51. Wood, T.M.; Bhat, K.M. Methods for Measuring Cellulase Activities. Methods Enzymol. 1988, 160, 87-112.

52. Cakmak, I.; Horst, W.J. Effect of Aluminium on Lipid Peroxidation, Superoxide Dismutase, Catalase, and Peroxidase Activities in Root Tips of Soybean (Glycine max). Physiol Plant. 1991, 83, 463-468. [CrossRef]

53. Velikova, V.; Yordanov, I.; Edreva, A. Oxidative Stress and Some Antioxidant Systems in Acid Rain-Treated Bean Plants: Protective Role of Exogenous Polyamines. Plant Sci. 2000, 151, 59-66. [CrossRef]

54. Beutler, H.O.; Michal, G. Methods of Enzymatic Analysis V4, 2nd ed.; Bergmeyer, H.U., Ed.; Academic Press: New York, NY, USA, 1974; pp. 1708-1713.

55. Grieve, C.M.; Grattan, S.R. Rapid Assay for Determination of Water Soluble Quaternary Ammonium Compounds. Plant Soil 1983, 70, 303-307. [CrossRef]

56. Bates, L.S.; Waldren, R.P.; Teare, I.D. Rapid Determination of Free Proline for Water-Stress Studies. Plant Soil 1973, 39, 205-207. [CrossRef]

57. Losak, T.; Hlusek, J.; Filipcik, R.; Pospisilova, L.; Manasek, J.; Prokes, K. Effect of Nitrogen Fertilization on Metabolism of Essential and Non-Essential Amino Acids Field-Grown Grain Maize (Zea mays L). Plant Soil Environ. 2010, 56, 574-579. [CrossRef]

58. Griffith, O.W. Determination of Glutathione and Glutathione Disulfide Using Glutathione Reductase and 2-vinylpyridine. Anal. Biochem. 1980, 106, 207-212. [CrossRef]

59. Wolf, B. A Comprehensive System of Leaf Analyses and Its Use for Diagnosing Crop Nutrient Status. Commun. Soil Sci. Plant Anal. 1982, 13, 1035-1059. [CrossRef]

60. Bremner, J.M.; Keeney, D.R. Steam Distillation Methods for the Determination of Ammonium, Nitrate, and Nitrite. Anal. Chim. Acta 1965, 32, 485-495. [CrossRef]

61. Ali, Q.; Ashraf, M. Induction of Drought Tolerance in Maize (Zea mays L.) Due to Exogenous Application of Trehalose: Growth, Photosynthesis, Water Relations and Oxidative Defence Mechanism. J. Agron. Crop Sci. 2011, 197, 258-271. [CrossRef]

62. Jamil, S.; Ali, Q.; Iqbal, M.; Javed, M.T.; Iftikhar, W.; Shahzad, F.; Perveen, R. Modulations in Plant Water Relations and Tissue-Specific Osmoregulation by Foliar-Applied Ascorbic Acid and the Induction of Salt Tolerance in Maize Plants. Brazilian J. Bot. 2015, 38, 527-538. [CrossRef]

63. Ali, Q.; Ashraf, M. Exogenously applied glycinebetaine enhances seed and seed oil quality of maize (Zea mays L.) under water deficit conditions. Env. Exp. Bot. 2011, 71, 249-259. [CrossRef]

64. Ge, T.; Song, S.; Roberts, P.; Jones, D.L.; Huang, D.; Iwasaki, K. Amino acids as a nitrogen source for tomato seedlings: The use of dual-labeled $(13 \mathrm{C}, 15 \mathrm{~N})$ glycine to test for direct uptake by tomato seedlings. Environ. Exp. Bot. 2009, 66, 357-361. [CrossRef]

65. Fahimi, F.; Souri, M.K.; Yaghoubi Sooraki, F. Growth and Development of Greenhouse Cucumber Under Foliar Application of Biomin and Humifolin Fertilizers in Comparison to Their Soil Application and NPK. J. Sci. Technol. Greenh. Cult. 2016, 7, 143-152. [CrossRef]

66. Ghasemi, S.; Khoshgoftarmanesh, A.H.; Hadadzadeh, H.; Jafari, M. Synthesis of Iron-Amino Acid Chelates and Evaluation of Their Efficacy as Iron Source and Growth Stimulator for Tomato in Nutrient Solution Culture. J. Plant Growth Regul. 2012, 31, 498-508. [CrossRef]

67. Jie, M.; Raza, W.; Xu, Y.C.; Shen, Q.R. Preparation and Optimization of Amino Acid Chelated Micronutrient Fertilizer by Hydrolyzation of Chicken Waste Feathers and the Effects on Growth of Rice. J. Plant Nutr. 2008, 31, 571-582. [CrossRef]

68. Rafie, M.R.; Khoshgoftarmanesh, A.H.; Shariatmadari, H.; Darabi, A.; Dalir, N. Influence of Foliar-Applied Zinc in the Form of Mineral and Complexed with Amino Acids on Yield and Nutritional Quality of Onion Under Field Conditions. Sci. Hortic. 2017, 216, 160-1688. [CrossRef]

69. Aldesuquy, H.S.; Ibraheem, F.L.; Ghanem, H.E. Assessment of Salicylic Acid and Trehalose Impact on Root Growth and Water Relations in Relation to Grain Yield of Droughted Wheat Cultivars. Nutri. Food Sci. Int. J. 2018, 7, NFSIJ.MS.ID.555701. 
70. Hussain, H.A.; Men, S.; Hussain, S.; Chen, Y.; Ali, S.; Zhang, S.; Zhang, K.; Li, Y.; Xu, Q.; Liao, C.; et al. Interactive Effects of Drought and Heat Stresses on Morphophysiological Attributes, Yield, Nutrient Uptake and Oxidative Status in Maize Hybrids. Sci. Rep. 2019, 9, 3890. [CrossRef] [PubMed]

71. Hayat, S.; Hayat, Q.; Alyemeni, M.N.; Wani, A.S.; Pichtel, J.; Ahmad, A. Role of Proline Under Changing Environments. A review. Plant Signal. Behav. 2012, 7, 1456-1466. [CrossRef] [PubMed]

72. Buttery, B.R.; Buzzell, R.I. The Relationship Between Chlorophyll Content and Rate of Photosynthesis in Soybeans. Can. J. Plant Sci. 1977, 57, 1-5. [CrossRef]

73. Rahbarian, R.; Khavari-Nejad, R.; Ganjeali, A.; Bagheri, A.; Najafi, F. Drought Stress Effects on Photosynthesis, Chlorophyll Fluorescence and Water Relations in Tolerant and Susceptible Chickpea (Cicer arietinum L.) Genotypes. Acta B. Crac. Ser. Bot. 2011; 53/1, 47-56. [CrossRef]

74. Hussein, M.M.; Kassab, O.M.; Ellil, A.A. Evaluating Water Stress Influence on Growth and Photosynthetic Pigments of Two Sugar Beet Varieties. Res. J. Agric. Biol. Sci. 2008, 4, 936-941.

75. Farooq, M.; Wahid, A.; Kobayashi, N.; Fujita, D.; Basra, S.M.A. 2009. Plant Drought Stress: Effects, Mechanisms and Management. Agron. Sustain. Dev. 2009, 29, 153-188. [CrossRef]

76. Akhtar, S.; Bangash, N.; Shahzad, A.; Fatima, S.; Nayab, D.; Arshad, M.; Iqbal, M.S.; Akbar, M.; Khalil, T.; Hassan, F. Foliar Applications of $\mathrm{FeSO}_{4}$ Alone and in Combination With Citric Acid Can Reduce Iron Deficiency Induced Chlorosis in Two Pakistani Peanut (Arachis hypogaea L.) Varieties. Appl. Ecol. Environ. Res. 2018, 16, 2873-2884. [CrossRef]

77. Rajitha, B.; Latha, P.; Sudhakar, P.; Umamahesh, V. A Comparative Study on the Effect of Foliar Application of Nitrogen, Phosphorus, Potassium, Iron and Zinc on Proline Content, Yield and Cost- Benefit Ratio of Groundnut Plants Grown Under Water Stress Conditions. Int. J. Pure App. Biosci. 2018, 6, 784-789. [CrossRef]

78. Hanson, A.D.; Gregory III, J.F. Folate Biosynthesis, Turnover, and Transport in Plants. Ann. Rev. Plant Biol. 2011, 62, 105-125. [CrossRef]

79. Evans, L.T. The Effect of Light on Plant Growth, Development and Yield. In Plant Response to Climatic Factors; Slatyer, R.O., Ed.; UNESCO: Paris, France, 1973; pp. 21-35.

80. Ojima, M. Improvement of Photosynthetic Capacity in Soybean Variety. Jap. Agric. Res. 1974, 8, 6-12.

81. Watanabe, I. Mechanism of Varietal Differences in Photosynthetic Rate of Soybean Leaves. 1. Correlations Between Photosynthetic Rates and Some Chloroplast Characters. Crop Sci. Soc. Jap. 1973, 42, 377-386. [CrossRef]

82. Kariya, K.; Tsunoda, S. Relationship of Chlorophyll Content, Chloroplast Area Index and Leaf Photosynthesis Rate in Brassica. Tohoku J. Agric. Res. 1972, 23, 1-14.

83. El-Esawi, M.A.; Alaraidh, I.A.; Alsahli, A.A.; Ali, H.M.; Alayafi, A.A.; Witczak, J.; Ahmad, M. Genetic variation and alleviation of salinity stress in barley (Hordeum vulgare L.). Molecules 2018, 23, 2488. [CrossRef] [PubMed]

84. El-Esawi, M.A.; Al-Ghamdi, A.A.; Ali, H.M.; Alayafi, A.A.; Witczak, J.; Ahmad, M. Analysis of Genetic Variation and Enhancement of Salt Tolerance in French Pea (Pisum Sativum, L.). Int. J. Mol. Sci. 2018, 19, 2433. [CrossRef]

85. El-Esawi, M.A.; Al-Ghamdi, A.A.; Ali, H.M.; Alayafi, A.A. Azospirillum lipoferum FK1 confers improved salt tolerance in chickpea (Cicer arietinum L.) by modulating osmolytes, antioxidant machinery and stress-related genes expression. Environ. Exp. Bot. 2019, 159, 55-65. [CrossRef]

86. Elkelish, A.A.; Soliman, M.H.; Alhaithloul, H.A.; El-Esawi, M.A. Selenium protects wheat seedlings against salt stress-mediated oxidative damage by up-regulating antioxidants and osmolytes metabolism. Plant Physiol. Biochem. 2019, 137, 144-153. [CrossRef]

87. El-Esawi, M.A.; Elkelish, A.; Elansary, H.O.; Ali, H.M.; Elshikh, M.; Witczak, J.; Ahmad, M. Genetic transformation and hairy root induction enhance the antioxidant potential of Lactuca serriola L. Oxid. Med. Cell. Longev. 2017, 2017, 5604746. [CrossRef]

88. Amirinejad, M.; Akbari, G.A.; Baghizadeh, A.; Allahdadi, I.; Shahbazi, M.; Naimi, M. Effects of Drought Stress and Foliar Application of Zinc and Iron on Some Biochemical Parameters of Cumin. J. Crops Improv. 2016, 17, 855-866.

89. Taize, L.; Zeiger, E.; Moller, I.M.; Murphy, A. Plant Physiology and Development, 6th ed.; Sinauer Associates Inc. Publishers: Sunderland, MA, USA, 2015. 
90. Mazher, A.A.; Zaghloul, S.M.; Mahmoud, S.A.; Siam, H.S. Stimulatory Effect of Kinetin, Ascorbic Acid and Glutamic Acid on Growth and Chemical Constituents of Codiaeum variegatum L. Plants. Am. Eurasian J. Agric. Environ. Sci. 2011, 10, 318-323.

91. Ramezani, A.; Sajedi, N.A.; Yarahmadi, H.M. The Effect of Foliar Application of Iron, Zinc, and Selenium on Nutrient Uptake and Yield of Alfalfa. Int. Res. J. Appl. Basic Sci. 2019, 10, 557-562. 